\title{
LA EXCEPCIÓN DEL ORDEN PÚBLICO INTERNACIONAL: ESTUDIO COMPARADO ENTRE EL SISTEMA ESPAÑOL Y ALEMÁN EN SUSPUESTOS DE DIVORCIO
}

\author{
THE INTERNATIONAL PUBLIC POLICY EXCEPTION: \\ A COMPARATIVE STUDY OF THE SPANISH AND GERMAN \\ SYSTEMS IN DIVORCE CASES
}

\author{
Anna Pauline Schweinbach \\ Egresada en el Doble Grado en Derecho hispano-alemán entre la Universidad \\ de Bayreuth y la Universidad Pablo de Olavide \\ David CARrizo Aguado \\ Profesor Ayudante Doctor de Derecho internacional privado \\ Universidad de León \\ ORCID ID: 0000-0002-9427-287X
}

Recibido: 09.07.2021 / Aceptado: 27.07.2021

DOI: https://doi.org/10.20318/cdt.2021.6252

\begin{abstract}
Resumen: En el presente estudio se realiza una introspección legal y jurisprudencial del orden público internacional en supuestos de divorcio con elemento extranjero desde un enfoque de derecho comparado entre el régimen español y alemán ante la dificultosa, pero creciente convivencia con instituciones del mundo islámico, tal y como sucede con el repudio. Se abordan cuestiones, esencialmente, sobre ley aplicable y reconocimiento de divorcios extranjeros, con especial consideración en las consecuencias que ello supone frente a la armonización del Derecho internacional privado europeo. Debido a la exclusión material del divorcio privado, en aras del Reglamento (UE) 1259/2010, el repudio se rige por cláusulas de orden público internacional de distintas naturalezas jurídicas. Su cuestionado art. 10, aplicable por referencia en España, implica una relajación de los criterios sostenidos tradicionalmente, facilitando su invocación frente al repudio, mientras que su vigencia en Alemania aminora el uso de la figura

Palabras clave: orden público internacional, Derecho comparado, crisis matrimonial transfronteriza, ley aplicable, reconocimiento.

Abstract: In this paper, a legal and jurisprudential introspection of international public order is carried out in cases of divorce with a foreign element from a comparative legal approach between the Spanish and German regimes in the face of the difficult, but growing coexistence with institutions of the Islamic world, as it happens with repudiation. Issues are addressed, essentially, on applicable law and recognition of foreign divorces, with special consideration of the consequences that this entails in the face of the harmonization of European private international law. Due to the material exclusion of private divorce, for the sake of Regulation (EU) 1259/2010, the repudiation is governed by clauses of interna-
\end{abstract}

*Este trabajo se ha realizado en el marco del proyecto de investigación $\mathrm{I}+\mathrm{D}+\mathrm{i}$ "Retos de la regulación jurídico-patrimonial del matrimonio y de otras realidades (uniones de hecho) en los planos supraestatal y estatal (REJURPAT)" PID2019106496RB-I00 del que es Investigador Principal el Prof. Dr. Andrés Rodríguez Benot. 
tional public order of different legal natures. His questioned art. 10, applicable by reference in Spain, implies a relaxation of the criteria traditionally held, facilitating its invocation in the face of repudiation, while its validity in Germany reduces the use of the figure

Keywords: international public policy, comparative law, foreign private divorce, cross-border matrimonial crisis, applicable law, recognition, conflict of laws

Sumario: I. Aspectos introductorios. 1. Acercamiento a una realidad controvertida: el orden público internacional. 2. Función y efectos del orden público internacional. 3. El orden público internacional en sede de ley aplicable. 4 . El orden público internacional en sede de reconocimiento. II. Fuentes del orden público internacional. 1. Régimen jurídico español. 2. Régimen jurídico alemán. 3. Régimen europeo. 1. El orden público internacional en el Reglamento (UE) 1259/2010. 2. El orden público internacional en el Reglamento (CE) 2201/2003. III. Límites y control de aplicación. 1. Influencia de normas comunitarias en el orden público internacional. 2. Postura del TJUE sobre sus competencias de control de orden público internacional. 2.1. Idea preliminar. 2.2. El asunto Sahyouni. 2.3. Perspectivas futuras alrededor de un orden público europeo aplicable a repudios. IV. La compleja tarea de homologación del repudio. 1. Delimitación entre Talaq, repudio y divorcio. 2. Rasgos problemáticos del repudio. 2.1. Revocabilidad. 2.2. Unilateralidad. 2.3. Ausencia de intervención judicial. V. El orden público internacional en sede de ley aplicable. Análisis comparativo del enfoque español y alemán. 1. Vulneración del principio de igualdad. 2. Intensidad de la incompatibilidad. 3. Ámbito de control. 4. Relatividad del orden público internacional. 4.1. Relatividad espacial. 4.2. Relatividad temporal. 5. Efectos. VI. El orden público internacional en sede de reconocimiento. Análisis comparativo del enfoque español y alemán. 1. Requisitos para el reconocimiento de divorcios privados. 1.1. Acto de una autoridad estatal. 1.2. Vulneración de garantías procesales. 2. Intensidad de la incompatibilidad. 3. Ámbito de control. 4. Efectos atenuantes. VII. A modo de reflexión fina

\section{Aspectos introductorios}

\section{Acercamiento a una realidad controvertida: el orden público internacional}

1. De todo es muy bien sabido que, el Derecho Internacional Privado ha de servir como canal de comunicación intercultural, esto es, entre realidades culturales diversas ${ }^{1}$. No obstante, el concepto del automatismo de la aplicación de leyes extranjeras parte de la idea de ordenamientos "sustancialmente equivalentes" es multicultural; en este sentido, Alemania posee excelsa experiencia con sucesivas generaciones de inmigrantes desde estados con tradición islámica mientras que España se ha convertido en un país de inmigración más recientemente 3 . Los estados cuyos sistemas jurídicos se inspiran en las disposiciones del islam tienen una comprensión social distinta a la occidental.

2. La apariencia de figuras jurídicas desconocidas ante tribunales europeos hace imprescindible la excepción del orden público internacional como mecanismo jurídico protector de los valores considerados esenciales en el foro. Su campo de actuación elemental es el Derecho de familia ${ }^{4}$ que se rige

${ }^{1}$ S. SÁnchez Lorenzo, "Postmodernismo y Derecho internacional privado", Revista Española de Derecho Internacional, vol. 46, núm. 2, 1994, pp. 557-585, citado por H. Aguilar Grieder, "Multiculturalidad, reconocimiento en España de repudios islámicos pronunciados en el extranjero y actuales tendencias del orden público en el D.I.Pr.", Cuestiones actuales de derecho comparado: actas de las reuniones académicas celebradas el 13 de julio de 2001 y el 10 de octubre de 2002 en la Facultad de Derecho de A Coruña, 2003, pp. 235-264.

2 J. Carrascosa González, "Orden público internacional y externalidades negativas", Boletín del Ministerio de Justicia, año 63, núm. 2065, 2008, pp. 5-32.

${ }^{3}$ H. Aguilar Grieder, "Multiculturalidad, reconocimiento en España de repudios islámicos pronunciados en el extranjero y actuales tendencias del orden público en el D.I.Pr.", Cuestiones actuales de derecho comparado: actas de las reuniones académicas celebradas el 13 de julio de 2001 y el 10 de octubre de 2002 en la Facultad de Derecho de A Coruña, 2003, pp. 235-264.

${ }^{4} C f$. D. BAetKe, "Band 6: Internationales Privatrecht und UN-Kaufrecht: Art. 6 EGBGB“, en M. WÜrdinger (ed.), Juris PraxisKommentar BGB, 9.a ed., Juris GmbH, Saarbrücken, 2020. 
por valores "de carácter estructural, básico e inderogable", tales como la igualdad de los cónyuges y el interés del menor.

Así las cosas, el fenómeno migratorio da lugar a una internacionalización de las relaciones familiares ${ }^{6}$. En un mundo globalizado, no es inhabitual que un matrimonio se disuelva en un país distinto a aquel de su constitución ${ }^{7}$. Sirva como ejemplo, el repudio el cual resulta la modalidad más usual de disolución de matrimonio en el mundo islámico ${ }^{8}$ y exige a los tribunales europeos el desarrollo de una técnica uniforme para su homologación.

3. En lo que aquí atañe, el orden público internacional equivale a un "Camaleón", esto es, un concepto abstracto para garantizar su empleo versátil en un número indeterminado de supuestos futuros y variable en función de la realidad social ${ }^{10}$. A la vez, tiene el inconveniente de ser difícil de captar, pues su noción es "en extremo sutil, imprecisa e indeterminada"".

El término orden indica una noción estabilizadora, constituye el "edificio jurídico general" sin el cual el sistema "se vendría abajo" defendidos pertenecen a un colectivo social ${ }^{13}$. Se derivan de una experiencia social continuada que demostró su indispensabilidad para el grupo concreto ${ }^{14}$. Ello convierte al orden público internacional en "más nacional que internacional" 15 : el término internacional no hace referencia a un conjunto de valores compartidos por la comunidad internacional, sino a aquella parte de los valores nacionales con transcendencia en el tráfico externo ${ }^{16}$. Cada estado los define de modo distinto, por lo que el contenido del orden público varía de un país a otro ${ }^{17}$. Aunque los principios jurídicos básicos alemanes y españoles son bastante similares, el ejemplo del repudio demuestra la subsistencia de visiones divergentes hacia el divorcio.

4. Frente al marcado carácter nacional del orden público internacional, el proceso armonizador del Derecho internacional privado dentro de la UE influye en la frecuencia del uso de la figura. A la hora de su aplicación, Alemania y España se mueven dentro del mismo marco establecido por las normas del Derecho internacional privado europeo, el derecho comunitario primario y los principios de origen supra e internacional. Esa igualdad de condiciones sugiere un enfoque común: para apreciar la probabilidad

${ }^{5}$ J. CARrascosa GonzÁlez, "Orden público internacional y externalidades negativas", Boletín del Ministerio de Justicia, año 63, núm. 2065, 2008, pp. 5-32.

${ }^{6} C f$. N. Magallón ElóSEgui, "Reconocimiento y ejecución parcial de resoluciones judiciales extranjeras y orden público en la Ley de Cooperación Jurídica Internacional en materia civil. Comentario al auto de la Audiencia Provincial de Gipuzkoa (Sección 2ª núm. 120/2018, de 9 de marzo", Cuadernos de Derecho Transnacional, vol. 11, núm. 1, 2019, pp. 834-840.

${ }^{7}$ Cf. N. Marchal Escalona, "La eficacia en España de los divorcios extrajudiciales otorgados en el extranjero", Cuadernos de Derecho Transnacional, vol. 13, núm. 1, 2021, pp. 460-492.

${ }^{8}$ Cf. A. QuiÑones Escámez, "La disolución del matrimonio: especial referencia al repudio islámico", en A. Rodríguez BENOT (ed.), La multiculturalidad: Especial referencia al Islam, Consejo General del Poder Judicial, Madrid, 2002, pp. 259-342.

${ }^{9}$ B. Dutort, "L`ordre public: caméléon du droit international privé", en B. Dutort et al. (ed.), Mélanges Guy Flattet: recueil de travail offerts à M. Guy Flattet, Lausanne, 1985, citado por J. CARRASCOSA GonZÁLEz, "Orden público internacional y externalidades negativas", Boletín del Ministerio de Justicia, año 63, núm. 2065, 2008, pp. 5-32.

${ }^{10}$ Cf. STS 23/11/1995, citada por Ma .A. Gaitón Redóndo, “Artículo 12 del Código Civil”, en P. Martorell Zulueta (ed.), Código civil con jurisprudencia sistematizada, $3^{\mathrm{a}}$ ed., Tirant lo Blanch, Valencia, pp. 215-217.

${ }^{11}$ ATS 24/10/1979.

${ }^{12}$ J. Carrascosa GonzÁlez, "Orden público internacional y externalidades negativas”, Boletín del Ministerio de Justicia, año 63, núm. 2065, 2008, pp. 5-32.

${ }^{13}$ Cf. ibid.

${ }^{14} C f$. L.A. López Zamora, "Comentarios sobre el Orden Público Internacional en sede arbitral internacional, su funcionalidad y su interrelación con el Derecho internacional público", Cuadernos de Derecho Transnacional, vol. 10, núm. 2, 2018, pp. 516-535.

${ }^{15}$ J. Carrascosa GonzÁlez, “Orden público internacional y externalidades negativas”, Boletín del Ministerio de Justicia, año 63, núm. 2065, 2008, pp. 5-32.

${ }^{16}$ Cf. C. Esplugues Mota, "La determinación del Derecho aplicable a las situaciones jurídico-privadas internacionales: aplicación práctica de la norma de conflicto”, en J.L. Iglesias BuHigues et al. (ed.), Derecho internacional privado, 14ª ed., Tirant lo Blanch, Valencia, pp. 239-260.

${ }^{17} C f$. J. Carrascosa GonzÁlez, "Orden público internacional y externalidades negativas", Boletín del Ministerio de Justicia, año 63, núm. 2065, 2008, pp. 5-32. 
de un orden público internacional europeo uniforme es preciso examinar si sus regulaciones nacionales armonizan o si existen divergencias en el uso de la figura que lo impiden. Por ello, la comparación entre el orden público internacional español y alemán no constituye un fin en sí mismo.

5. Por consiguiente, se pretende analizar cómo se aplica el orden público internacional dentro de los mismos límites constituidos por los objetivos de la UE y los intereses del tráfico externo: ¿se puede observar una aproximación del uso de la excepción del orden público internacional en los dos países comparando el respectivo enfoque frente al repudio? O, por el contrario, ¿se utiliza al orden público internacional como mecanismo de aislamiento nacional a pesar de la tendencia armonizadora en el Derecho internacional privado?

\section{Función y efectos del orden público internacional}

6. La norma de conflicto es la regla general y favorable a la aplicación de un derecho extranjero, mientras que la intervención del orden público internacional es la regla excepcional y contraria a la aplicación de un derecho extranjero" ${ }^{18}$. El orden público internacional desactiva la ley extranjera cuando el resultado de su aplicación al caso concreto sea incompatible con los principios jurídicos esenciales del fuero. Las normas de conflic o suponen un "salto en la oscuridad" 19 al convocar una ley cuyo contenido sustantivo es imprevisible ${ }^{20}$. Una solución favorable para el litigante extranjero podría implicar un perjuicio para la "estructura jurídica básica"21 del foro.

7. En una primera fase, el operador jurídico examina la norma extranjera en cuanto a su contenido material, alcance y el resultado hipotético ${ }^{22}$. Una vez contrastados los resultados según la lex fori y la lex causae, tendrá base suficiente para deducir la relevancia de ciertos principios que choquen con la regulación de la ley extranjera ${ }^{23}$. Así, tendrá lugar una ponderación entre el interés de los litigantes confiando en la vigencia de la norma de conflicto ${ }^{24}$ del estado garantizador de los valores esenciales y de la comunidad internacional interesada en el normal funcionamiento del tráfico extern ${ }^{25}$.

8. En cierto modo, el orden público internacional es una "norma de conflicto incompleta" 26 porque no proporciona por sí sola una solución sustantiva al caso. Su función negativa se refleja en la ausencia de una disposición relativa a la ley aplicable en su defecto. Es decir, el orden público internacional constituye una "válvula de seguridad", ${ }^{27}$ se limita a la defensa emergente del núcleo de valores,

${ }^{18}$ A.L. Calvo Caravaca \& J. Carrascosa González, "Crisis matrimoniales", en A.L. Calvo Caravaca/ J. Carrascosa GonzÁlez (eds.), Derecho Internacional Privado: Vol. II, $18^{\mathrm{a}}$ ed., Comares, Granada, 2018, pp. 227-314.

${ }^{19}$ L. RAape / F. Sturm, "Internationales Privatrecht: Vol. I“, 6a ed., Verlag Franz Vahlen, München, 1934, citado por B. v. Hoffmann \& K. Thorn, “ §6. Grundbegriffe: Ordre Public“, en B. v. Hoffmann \& K. Thorn (eds.), Internationales Privatrecht, 9a ed., C.H. Beck, Múnich, 2007, pp. 136-154.

${ }^{20}$ Cf. J. Carrascosa GonzÁlez, "Orden público internacional y externalidades negativas", Boletín del Ministerio de Justicia, año 63, núm. 2065, 2008, pp. 5-32.

${ }^{21}$ Ibid.

${ }^{22}$ Cf. J.D. González Campos \& J.C. Fernández Rozas, “Orden público como correctivo funcional: Artículo 12, Apartado 3 del Código Civil”, en M. Albaladejo \& S. Díaz Alabart (eds.), Comentarios al Código Civil y Compilaciones forales, $5^{\mathrm{a}}$ ed., Edersa, Madrid, 1995, pp. 894-926.

${ }^{23}$ Cf. J. Carrascosa GonzÁlez, "Orden público internacional y externalidades negativas", Boletín del Ministerio de Justicia, año 63, núm. 2065, 2008, pp. 5-32.

${ }^{24}$ Cf. ibid.

${ }^{25}$ Cf. A. Ybarra Bores, "Los problemas de aplicación del sistema de derecho internacional privado", en A. RodríGuez Benot et al. (ed.), Manual de derecho internacional privado, $6^{\text {a }}$ ed., Tecnos, Madrid, 2019, pp. 149-162.

${ }^{26}$ M. Voltz, "IPR - Allgemeiner Teil: Art. 3 - 6 EGBGB“, en D. HenRICH (ed.), J. von Staudingers Kommentar zum Bürgerlichen Gesetzbuch mit Einführungsgesetz und Nebengesetzen, Otto Schmidt/De Gruyter Verlag OHG, Berlín, 2013.

${ }^{27}$ J.D. González Campos \& J.C. Fernández Rozas, "Orden público como correctivo funcional: Artículo 12, Apartado 3 del Código Civil”, en M. Albaladejo \& S. Díaz Alabart (eds.), Comentarios al Código Civil y Compilaciones forales, $5^{\mathrm{a}}$ ed., Edersa, Madrid, 1995, pp. 894-926. 
imprescindibles incluso en supuestos de tráfico externo. El silencio relativo a la ley aplicable refleja la prevalencia del principio de cooperación en el plano internacional, pues no se trata de promover los valores de la lex fori mediante su aplicación subsidiaria automática.

\section{El orden público internacional en sede de ley aplicable}

9. La excepción del orden público internacional de ley aplicable se materializa cuando la norma extranjera señalada como lex causae prevé una solución al caso concreto que es incompatible con el orden público internacional del fuero.

El objeto cuya contrariedad se investiga por el operador jurídico es una norma jurídica. La fin lidad de los litigantes consiste en crear en el foro una situación jurídica conforme a una ley extranjera. El lugar en el que la decisión surtirá efectos suele coincidir con el foro. Cuando se pretenda crear una situación jurídica ahí, el orden público "opera de modo total, completo y radical" 28 . Como consecuencia jurídica, se elude la constitución de la situación jurídica conforme a los preceptos de la ley extranjera.

\section{El orden público internacional en sede de reconocimiento}

10. El orden público internacional en el contexto del reconocimiento ha lugar cuando se pretende conferir efecto a una situación jurídica creada legalmente en el extranjero. El objeto, cuya compatibilidad con el orden público internacional se examina, no es la norma jurídica en sí, sino la decisión de una autoridad extranjera sobre la base de un ordenamiento jurídico extranjero ${ }^{29}$. El litigante desea continuidad trasfronteriza, es decir, la extensión de los efectos de la situación jurídica creada anteriormente. Suelen ser situaciones que no solamente han surgido en el extranjero, sino que además han surtido sus efectos principales en otro país, normalmente careciendo de un nexo con el fuero ${ }^{30}$. Sin embargo, el lugar dónde el reconocimiento surtirá sus efectos pueda variar. Una vez activado, el orden público de reconocimiento evita que la situación jurídica creada en el extranjero surta efectos en el fuero. No obstante, sigue presentando plena efectividad en el lugar de constitución.

11. A diferencia de lo acaecido en ley aplicable, el orden público internacional de reconocimiento no opera plenamente. Cabe distinguir entre los efectos nucleares y los efectos periféricos. Se consideran nucleares todos los efectos derivados del reconocimiento que perjudican a los principios esenciales del foro ${ }^{31}$. Aquí es donde opera el orden público en la misma intensidad que en relación con la ley aplicable. Por el contrario, los efectos periféricos son aquellos que se consideran compatibles con el orden público internacional admitiéndose sin perjuicio del rechazo del efecto nuclear.

12. Por consiguiente, el orden público internacional está dividido en dos categorías. De un lado, la incompatibilidad con las garantías procesales del foro da lugar al orden público internacional procesal. Por otro lado, una incompatibilidad con el contenido jurídico-material de la decisión extranjera activa el orden público internacional material.

${ }^{28}$ J. Carrascosa GonzÁlez, "Orden público internacional y externalidades negativas”, Boletín del Ministerio de Justicia, año 63, núm. 2065, 2008, pp. 5-32.

${ }^{29} C f$. M. Frey \& L. PfeIfER, „Der ordre public - die öffentliche Ordnung: derselbe Begriff, verschiedene Funktionen - ein Rechtsprinzip?“, Europarecht, vol. 50, núm. 6, 2015, pp. 721-734.

${ }^{30}$ Cf. J. Carrascosa GonzÁlez, "Orden público internacional y externalidades negativas", Boletín del Ministerio de Justicia, año 63, núm. 2065, 2008, pp. 5-32.

${ }^{31}$ Cf. id. 


\section{Fuentes del orden público internacional}

\section{Régimen jurídico español}

13. El art. 12.3 del Código civil español $(\mathrm{CC})$ recoge la cláusula general de orden público internacional en el marco de la ley aplicable ${ }^{32}$. Su última modificación coincidió con la reforma del Título Preliminar del código civil en 1974 que pretendía una mejor adecuación del Derecho internacional privado a las exigencias del tráfico extern ${ }^{33}$.

14. En contraste con las cláusulas de orden público internacional de origen internacional ${ }^{34}$, carece del adjetivo manifiestamente contrario. Dicha ausencia ha sido interpretada por la doctrina de distinto modo. Algunos autores consideran prescindible su inclusión porque una interpretación a la luz de los tratados internacionales suscritos por España obliga a entender el art. 12.3 CC en el sentido de manfiest $a^{35}$. En cambio, otro sector entiende que, la exclusión del término demuestra que el legislador no tenía suficientemente presente los instrumentos internacionales en el ámbito del Derecho internacional privado ni su influencia en la aplicabilidad del orden público internacional español ${ }^{36}$. No debe caer en baldío que, la modificación de la cláusula cae dentro de una época en la cual España suscribía un número elevado de tratados internacionales de Derecho internacional privado, convirtiéndose la regulación del orden público, enmarcada por el artículo $12.3 \mathrm{CC}$, en meramente residual. Por ello, cierto sector doctrinal estima que, favorecería añadir al Capítulo IV del Título Preliminar un precepto que recoja la primacía de los tratados internacionales en el ámbito del Derecho internacional privado ${ }^{37}$ para facilitar la interpretación de la cláusula del orden público internacional doméstico en el sentido de una incompatibilidad manifiesta.

En ningún caso, debe ser equiparado con divergente, porque la existencia de un resultado meramente distinto a la solución ofrecida por la lex fori no presupone un daño para la sociedad española ${ }^{38}$.

15. Otro problema constituye el término ambiguo orden público ${ }^{39}$. La delimitación entre su noción amplia y restrictiva se logra mediante una interpretación sistemática. La expresión internacional es prescindible porque el art. 12.3 CC se sitúa en el Capítulo IV del Título Preliminar dedicado a normas de Derecho internacional privado que se caracterizan por ser aplicables a supuestos de tráfico externo ${ }^{40}$. El orden público en el sentido del art. 12.3 CC no hace referencia al conjunto de normas imperativas, sino a aquellos principios "susceptibles de ser extrapolados al plano internacional"41. Así, queda confirmado por la regla general del art. $12.6 \mathrm{CC}$ en lo que respecta a la aplicación automática de la ley extranjera ${ }^{42}$.

\footnotetext{
${ }^{32}$ Cf. ibid.

${ }^{33}$ Ibid.

${ }^{34}$ Vid. e.g. art. 12 del Reglamento (UE) N ${ }^{\circ}$ 1259/2010.

${ }^{35} \mathrm{Cf}$. A. Ybarra Bores, "Los problemas de aplicación del sistema de derecho internacional privado", en A. RodríGuez BenOt et al. (ed.), Manual de derecho internacional privado, $6^{\text {a }}$ ed., Tecnos, Madrid, 2019, pp. 149-162.

${ }^{36}$ Cf. J.C. Fernández Rozas, "El Capítulo IV del Título Preliminar del Código civil ("Normas de Derecho internacional privado"): Veinticinco años después", en Colegio de Abogados de Madrid (ed.), Homenaje a Antonio Hernández Gil, 2001, pp. 2411-2447.

${ }^{37}$ Cf. ibid.

${ }^{38}$ Cf. J. Carrascosa GonzÁlez, "Orden público internacional y externalidades negativas", Boletín del Ministerio de Justicia, año 63, núm. 2065, 2008, pp. 5-32.

${ }^{39}$ Cf. J.D. GonzÁlez Campos/J.C. Fernández Rozas, “Orden público como correctivo funcional: Artículo 12, Apartado 3 del Código Civil”, en M. Albaladejo \& S. Díaz Alabart (eds.), Comentarios al Código Civil y Compilaciones forales, 5 a ed., Edersa, Madrid, 1995, pp. 894-926.

${ }^{40} C f$. J. Carrascosa GonzÁlez, "Orden público internacional y externalidades negativas", Boletín del Ministerio de Justicia, año 63, núm. 2065, 2008, pp. 5-32., A. YBARRA Bores, "Los problemas de aplicación del sistema de derecho internacional privado", en A. RodríGuez Benot et al. (ed.), Manual de derecho internacional privado, $6^{\mathrm{a}}$ ed., Tecnos, Madrid, 2019, pp. 149-162.

${ }^{41}$ C. Esplugues Mota, "La determinación del Derecho aplicable a las situaciones jurídico-privadas internacionales: aplicación práctica de la norma de conflicto", en J.L. Iglesias Buhigues et al. (ed.), Derecho internacional privado, 14a ed., Tirant lo Blanch, Valencia, pp. 239-260.

${ }^{42} C f$. J.A. Corriente Córdoba, "La excepción de orden público en el derecho internacional privado español", Anuario español de derecho internacional, núm. 2, 1975, pp. 125-168.
} 
16. Conviene tener en cuenta que, el carácter excepcional del orden público se justifica en base a tres elementos: en primer lugar, respecto de su objeto, no olvidemos que para que despliegue toda su virtualidad, el art. 12.3 CC tan sólo puede ser una ley extranjera. Rige, por tanto, una definición amplia, siendo indiferente su rango y naturaleza. No obstante, ha de ser de origen estatal, siendo excluidas las convenciones y reglas derivadas de usos internacionales, exempli gratia, la lex mercatoria ${ }^{43}$. El uso del orden público internacional en conflictos de leyes interregionales está expresamente prohibido por el art. 16.1.2 $2^{\mathrm{a}} \mathrm{CC}^{44}$.

En segundo término, el art. $12.3 \mathrm{CC}$ exige que su aplicación resulte incompatible con el orden público internacional. Esa finura gramatical conlleva dos consecuencias para el ámbito de control: por una parte, la excepción del orden público no ataca la norma extranjera en sí, sino que elude su resultado en el caso concreto ${ }^{45}, \mathrm{y}$, por otra, el orden público internacional sólo evita la aplicación de aquellos elementos de la ley extranjera cuyo resultado sea contrario, sin perjuicio de los preceptos restantes de la lex causae.

En tercer lugar, el carácter excepcional se plasma en el carácter negativo del art. $12.3 \mathrm{CC}$, pues no indica una ley supletoria aplicable en defecto de la ley extranjera y guarda silencio sobre el método de su determinación ${ }^{46}$. No existe unanimidad sobre el significado de su ausencia. Si bien, la doctrina considera que, el art. 12.3 CC contiene una laguna legal ${ }^{47}$. No obstante, la asunción de que el legislador no haya contemplado la necesidad de sustituir la ley extranjera incompatible con el orden público internacional no es concluyente porque la misma configuración es habitual para los preceptos supra- e internacionales. El silencio de la norma es intencional, aclarando que constituye una "válvula de seguridad" ${ }^{48}$ en vez de un mecanismo de imposición forzosa de la lex fori. En estrecha relación con su carácter negativo, la consecuencia jurídica del orden público español tiene carácter absoluto. Además, el término en ningún caso aclara que una vez detectado un resultado incompatible, el operador jurídico español no dispondrá de ningún margen de discrecionalidad para aplicar el precepto de todos $\operatorname{modos}^{49}$. Un resultado contrario a los principios esenciales de la sociedad española es considerado "intolerable" ${ }^{50}$, ergo indiscutible.

\section{Régimen jurídico alemán: el artículo 6 EGBGB}

17. Lo que destaca de la cláusula general alemana del orden público internacional en sede de ley aplicable, en comparación con el art. $12.3 \mathrm{CC}$, es su especial mención a los derechos fundamentales ${ }^{51}$.

Esa estructura dual tiene su raíz en la Sentencia Spanierbeschluss del Tribunal Constitucional de la República Federal Alemana (BVerfG) del 4 de mayo de 1971 ${ }^{52}$. Una ciudadana alemana divorciada

${ }^{43} C f$. J.D. González Campos \& J.C. Fernández Rozas, "Orden público como correctivo funcional: Artículo 12, Apartado 3 del Código Civil”, en M. Albaladejo \& S. Díaz Alabart (eds.), Comentarios al Código Civil y Compilaciones forales, $5^{\mathrm{a}}$ ed., Edersa, Madrid, 1995, pp. 894-926.

${ }^{44}$ Cf. C. Esplugues Mota, "La determinación del Derecho aplicable a las situaciones jurídico-privadas internacionales: aplicación práctica de la norma de conflicto", en J.L. IgLesias BuHigues et al. (ed.), Derecho internacional privado, 14ª ed., Tirant lo Blanch, Valencia, pp. 239-260.

${ }^{45}$ Cf. J. Carrascosa GonzÁlez, "Orden público internacional y externalidades negativas", Boletín del Ministerio de Justicia, año 63, núm. 2065, 2008, pp. 5-32.

${ }^{46}$ Cf. J.D. González Campos \& J.C. Fernández Rozas, "Orden público como correctivo funcional: Artículo 12, Apartado 3 del Código Civil”, en M. Albaladejo \& S. Díaz Alabart (eds.), Comentarios al Código Civil y Compilaciones forales, $5^{\mathrm{a}}$ ed., Edersa, Madrid, 1995, pp. 894-926.

${ }^{47}$ Cf. J. Carrascosa GonzÁlez, "Orden público internacional y externalidades negativas", Boletín del Ministerio de Justicia, año 63, núm. 2065, 2008, pp. 5-32.

${ }^{48}$ Supra cit. 28.

${ }^{49}$ Cf. J.D. González Campos \& J.C. Fernández Rozas, “Orden público como correctivo funcional: Artículo 12, Apartado 3 del Código Civil”, en M. Albaladejo \& S. Díaz Alabart (eds.), Comentarios al Código Civil y Compilaciones forales, $5^{\mathrm{a}}$ ed., Edersa, Madrid, 1995, pp. 894-926.

${ }^{50} \mathrm{Cf}$. J. Carrascosa GonzÁlez, "Orden público internacional y externalidades negativas”, Boletín del Ministerio de Justicia, año 63, núm. 2065, 2008, pp. 5-32.

${ }^{51}$ No tendrá aplicación la ley de otro estado cuando resulte manifiesta ente incompatible con los principios esenciales del derecho alemán. En particular, no tendrá aplicación cuando la aplicación sea incompatible con los derechos fundamentales

${ }^{52} \mathrm{Cf}$. A. Colombi СіассH, "Internationales Privatrecht, ordre public européen und Europäische Grundrechte“, Zentrum für Europäische Rechtspolitik an der Universität Bremen (ed.), núm. 1, 2008. 
quería contraer matrimonio con un español, no obstante, la ley española aplicable no permitía el divorcio. Estimando el recurso de amparo por motivo de la vulneración de la libertad de contraer matrimonio con arreglo al art. 6.1 de la Constitución Alemana (GG), el alto tribunal alemán consideró que el orden público internacional debía ser concebido como "irrupción de los derechos fundamentales en el Derecho internacional privado" 53 . La sentencia supuso la ruptura con una acepción antigua según la cual el orden público solamente defendía a los intereses organizativos estatales ${ }^{54}$.

18. Para conseguir una mayor trascendencia de los derechos fundamentales en el orden público internacional, el BVerfG había proporcionado dos opciones: O bien, desarrollar su derecho conflictua propio, o bien, integrarlos en la cláusula de orden público ${ }^{55}$. En este último caso, no procedería diferenciar entre una vulneración soportable o insoportable ${ }^{56}$. El legislador alemán optó por la segunda alternativa. Así pues, los intereses individuales gozan de una protección privilegiada a través de la segunda frase del actual art. 6 de la Ley Introductoria del Código civil alemán (EGBGB) ${ }^{57}$ De ahí se deriva una relajación de requisitos para el uso del orden público en relación con derechos constitucionalmente recogidos.

19. Así, en contraste con la primera frase, la aplicación de una ley extranjera incompatible se rechaza cuando es incompatible con el orden público internacional. La sustitución del término resulte por ser no exonera de un análisis del resultado hipotético que se derivaría de la norma extranjera en el caso concreto ${ }^{58}$, aunque no es preciso un examen de la intensidad de contrariedad: A contrario sensu de la frase primera del art. 6 EGBGB, la frase segunda no exige una contrariedad manifiesta entre el resultado de la ley extranjera y el orden público internacional ${ }^{59}$. Ergo, toda vulneración de los derechos fundamentales es contraria al orden público internacional, sea manifiesta o no. Aun así, cabe comprobar el alcance del derecho fundamental afectado, al ser preciso que éste sea destinado a surtir efectos en supuestos de tráfico extern ${ }^{60}$.

20. Otra diferencia entre el art. 6 EGBGB y el art. $12 \mathrm{CC}$ consiste en el uso del término difuso orden público. Ambos sistemas jurídicos consiguen la distinción entre el orden público y el orden público internacional mediante su colocación dentro de un capítulo destinado en exclusivo al tráfico externo. En el sistema alemán, su delimitación se ilustra además mediante el uso del término en francés (ordre public) para hacer referencia al orden público internacional cómo excepción del Derecho internacional privado. Su traducción y colocación en el art. 6 EGBGB supone un homenaje al art. 6 del código civil francés de 1804 que se considera la primera cláusula moderna de orden público internacional. ${ }^{61}$ Por lo contrario, el orden público interno o "ius cogens nacional”² aparece en su traducción alemana.

21. Al igual que el art. $12.3 \mathrm{CC}$, el objeto del art. $6 \mathrm{EGBGB}$ ha de ser la ley de otro estado. Ni las convenciones internacionales, ni las normas de los estados federales alemanes pueden ser inaplicados a

\footnotetext{
${ }^{53} C f$. BVerfG 04/05/1971, párr. 67.

${ }^{54} C f$. B. v. Hoffmann \& K. Thorn, “ $§ 6$. Grundbegriffe: Ordre Public“, en B. v. Hoffmann \& K. Thorn (eds.), Internationales Privatrecht, 9a ed., C.H. Beck, Múnich, 2007, pp. 136-154.

${ }^{55}$ Cf. BVerfG 04/05/1971, párr. 67.

${ }^{56}$ BVerfG 04/05/1971, citada por J. v. HeIn, "Internationales Privatrecht I - Allgemeiner Teil: Art. 6 EGBGB“, en F.J. SÄCKER et al. (ed.), Münchener Kommentar zum BGB, 8a ed., vol. 12, C.H. Beck, Múnich, 2020.

${ }^{57}$ Cf. ibid.

${ }^{58}$ Cf. M. Voltz, "IPR - Allgemeiner Teil: Art. 3 - 6 EGBGB“, en D. Henrich (ed.), J. von Staudingers Kommentar zum Bürgerlichen Gesetzbuch mit Einführungsgesetz und Nebengesetzen, Otto Schmidt/De Gruyter Verlag OHG, Berlín, 2013.

${ }^{59}$ Cf. B. v. Hoffmann \& K. Thorn, “ §6. Grundbegriffe: Ordre Public“, en B. v. Hoffmann \& K. Thorn (eds.), Internationales Privatrecht, 9a ed., C.H. Beck, Múnich, 2007, pp. 136-154.

${ }^{60} \mathrm{Cf}$. P. SchOLz, "Grundfälle zum IPR: Ordre public - Vorbehalt und islamisch geprägtes Recht - Teil 1 (Allgemeiner Teil)“, Zeitschrift für das Juristische Studium, núm. 2, 2010, pp. 185-197; B. v. HoffMann \& K. THORN, “ §6. Grundbegriffe: Ordre Public“, en B. v. Hoffmann \& K. Thorn (eds.), Internationales Privatrecht, 9a ed., C.H. Beck, Múnich, 2007, pp. 136-154.

${ }^{61} C f$. J.A. Corriente Córdoba, "La excepción de orden público en el derecho internacional privado español”, Anuario español de derecho internacional, núm. 2, 1975, pp. 125-168.

${ }^{62}$ M. Voltz, "IPR - Allgemeiner Teil: Art. 3 - 6 EGBGB“, en D. HenRich (ed.), J. von Staudingers Kommentar zum Bürgerlichen Gesetzbuch mit Einführungsgesetz und Nebengesetzen, Otto Schmidt/De Gruyter Verlag OHG, Berlín, 2013.
} 
través de la figura del orden público internacional ${ }^{63}$. Ello no impide que se invoque el orden público internacional contra normas extranjeras de Derecho internacional privado ${ }^{64}$. Sin perjuicio del régimen especial, tal y como queda especificado en la frase segunda del art. 6 EGBGB, por regla general se exige una incompatibilidad manifiesta con la ley extranjera. A diferencia del art. $12.3 \mathrm{CC}$, el art. 6 EGBGB adoptó el requisito derivado de los preceptos internacionales para recordar la excepcionalidad de su uso. Constituye una "obligación de motivación" ${ }^{65}$ y elude que el orden público internacional pueda ser usada como escudo contra ordenamientos jurídicos extranjeros ${ }^{66}$. El art. 6 EGBGB carece de una función positiva, pues no convoca a la ley alemana como lex causae residual. ${ }^{67}$ De igual manera que el art. $12.3 \mathrm{CC}$ guarda silencio relativo al método de determinación de la ley aplicable en defecto, lo que subraya su carácter excepcional.

\section{Régimen europeo}

\section{El orden público internacional en el Reglamento (UE) 1259/2010}

22. El Reglamento (UE) $1259 / 2010^{68}$ relativo a la ley aplicable al divorcio y a la separación judicial proporciona una serie de normas de conflictos para dar solución a conflictos de leyes en el ámbito de divorcios con elemento extranjero. Si la rama del derecho de familia es particularmente sensible y dependiente de la uniformidad de sentencias, ${ }^{69}$ ¿por qué sigue existiendo una cláusula de orden público internacional en ese ámbito que ponga en peligro dichos objetivos?

23. El creciente multiculturalismo en la zona comunitaria provoca el enfrentamiento de tribunales europeos con acepciones culturales y religiosas desconocidas ${ }^{70}$. Estas se plasman en las leyes extranjeras convocadas por las normas de conflicto del Reglamento, que como bien dice su art. 4 tienen eficacia erga omnes, es decir, podrá aplicarse la ley de un estado que no es miembro de la $\mathrm{UE}^{71}$.

En este sentido, determinados principios inspiradores que rigen el Derecho de familia, tal como la igualdad de los cónyuges, provocan un uso frecuente del orden público internacional. Al igual que existe un contraste entre cláusulas generales abstractas y específicas en el ámbito nacional ${ }^{72}$, el orden público internacional de tal norma se caracteriza por su dualidad. Por un lado, su art. 12 figura como "clásica excepción de orden público"73 dado su carácter abstracto y ambiguo. A diferencia de la cláusula general alemana, prescinde de una mención especial de los derechos fundamentales ${ }^{74}$. Su carácter ne-

${ }^{63}$ Cf. B. v. Hoffmann \& K. Thorn, “ §6. Grundbegriffe: Ordre Public“, en B. v. Hoffmann \& K. Thorn (eds.), Internationales Privatrecht, 9a ed., C.H. Beck, Múnich, 2007, pp. 136-154.; J. v. HeIN, "Internationales Privatrecht I - Allgemeiner Teil: Art. 6 EGBGB“, en F.J. SäcKer et al. (ed.), Münchener Kommentar zum BGB, 8a ed., vol. 12, C.H. Beck, Múnich, 2020.

${ }^{64}$ Cf. ibid.

${ }^{65}$ E. JAYME, "Methoden der Konkretisierung des ordre public im Internationalen Privatrecht", JuRIstische StudiengeSelLSCHAFt KarLSRUHe (ed.), núm. 183, C.F. Müller Juristischer Verlag, Heidelberg, 1985.

${ }^{66} C f$. B. v. Hoffmann \& K. Thorn“ $§ 6$. Grundbegriffe: Ordre Public“, en B. v. Hoffmann \& K. Thorn (eds.), Internationales Privatrecht, 9a ed., C.H. Beck, Múnich, 2007, pp. 136-154.

${ }^{67}$ Cf. ibid..

${ }^{68}$ Reglamento (UE) $\mathrm{n}^{\circ}$ 1259/2010 del Consejo, de 20 de diciembre de 2010, por el que se establece una cooperación reforzada en el ámbito de la ley aplicable al divorcio y a la separación judicial (DOUE núm. 343, de 29 de diciembre de 2010).

${ }^{69}$ Cf. B. v. Hoffmann \& K. Thorn“ §6. Grundbegriffe: Ordre Public“, en B. v. Hoffmann \& K. Thorn (eds.), Internationales Privatrecht, 9a ed., C.H. Beck, Múnich, 2007, pp. 136-154.

${ }^{70} C f$. J. v. HeIn, “Internationales Privatrecht I - Allgemeiner Teil: Art. 6 EGBGB“, en F.J. SÄCKER et al. (ed.), Münchener Kommentar zum BGB, 8a ed., vol. 12, C.H. Beck, Múnich, 2020.

${ }^{71} C f$. B. Campuzano Díaz, "El Reglamento (UE) N. ${ }^{\circ}$ 1259/2010, de 20 de diciembre de 2010, por el que se establece una cooperación reforzada en el ámbito de la ley aplicable al divorcio y a la separación judicial”, Revista de Derecho Comunitario Europeo, núm. 39, 2011, pp. 561-587.

${ }^{72}$ Vid. párr. 13 y 17.

${ }^{73}$ B. Campuzano Díaz, "El Reglamento (UE) N. ${ }^{\circ}$ 1259/2010, de 20 de diciembre de 2010, por el que se establece una cooperación reforzada en el ámbito de la ley aplicable al divorcio y a la separación judicial", Revista de Derecho Comunitario Europeo, núm. 39, 2011, pp. 561-587.

${ }^{74} C f$. J. v. HeIn, “Internationales Privatrecht I - Allgemeiner Teil: Art. 6 EGBGB“, en F.J. SÄCKER et al. (ed.), Münchener Kommentar zum BGB, 8a ed., vol. 12, C.H. Beck, Múnich, 2020. 
gativo aclara la excepcionalidad de su uso y la primacía de la uniformidad de sentencias salvaguardada por el reglamento. Por otro lado, el art. 10 destaca por la celeridad de su aplicación ${ }^{75}$. A diferencia del art. 12, hace referencia expresa a un derecho fundamental concreto: La prohibición de discriminación del art. 21.1 de la Carta de los Derechos Fundamentales de la UE, siendo el principio esencial protegido mediante el acceso igualitario de ambos sexos al divorcio ${ }^{76}$. Al igual que las cláusulas específicas de origen nacional ${ }^{77}$, el art. 10 se inspira en supuestos de uso frecuente del orden público internacional de una base jurídica concretada por la lex fori con el fin de conceder la máxima seguridad jurídica.

\section{El orden público internacional en el Reglamento (CE) 2201/2003}

24. Hay que partir de la base que el Reglamento (CE) no posee eficacia erga omnes, por lo que sólo será aplicable a decisiones judiciales de otros Estados Miembros ${ }^{78}$. Este planteamiento trae como consecuencia que, la cláusula de orden público internacional regulada por su art. 22 a) del Reglamento no sirve para denegar el reconocimiento de divorcios constituidos tras repudio en terceros estados con tradición islámica ${ }^{79}$. Asi, el repudio se rige por derecho comunitario en lo relativo a la ley aplicable, pero su reconocimiento es competencia del legislador nacional.

\section{Límites y control de aplicación}

\section{Influencia de normas comunitarias en el orden público internacional}

25. Una vez analizadas las fuentes del orden público internacional, es preciso analizar su operatividad en el marco normativo español y alemán.

Las normas fundamentales comunitarias tienen eficacia erga omnes, por lo que influyen en la interpretación y aplicación de normas nacionales ${ }^{80}$. La esfera comunitaria cuenta con cuatro niveles de creación normativa: El Derecho internacional privado nacional, el Derecho internacional privado comunitario, las constituciones nacionales y los preceptos fundamentales supra- e internacionales ${ }^{81}$ en concreto la Carta de los Derechos Fundamentales de la Unión Europea y la Convención Europea de Derechos Humanos.

26. A resultas de lo anterior, se deriva una superposición de valores recogidos tanto en la esfera nacional como en la comunitaria que se incorporan dentro del orden público internacional, pues se amparan valores nacionales mediante el uso de cláusulas formalmente comunitarias. Así pues, los jueces españoles y alemanes actúan "como juez europeo" 82 cuando aplican las cláusulas europeas de orden público internacional. No solo eso, sino que, en virtud del principio de cooperación mutua ${ }^{83}$ los tribunales de los Estados Miembros se comprometen al amparo de los valores supranacionales a través de las cláusulas de orden público internacional de origen nacional. En ese sentido, los intereses de la

\footnotetext{
${ }^{75} \mathrm{Cf}$. id.

${ }^{76} \mathrm{Cf}$. id.

${ }^{77}$ A.L. Calvo Caravaca \& J. Carrascosa González, "Crisis matrimoniales", en A.L. Calvo Caravaca \& J. Carrascosa GonzÁlez (eds.), Derecho Internacional Privado: Vol. II, $18^{\text {a }}$ ed., Comares, Granada, 2018, pp. 227-314.

${ }^{78}$ Vid. art. 21.1 BII-bis.

${ }^{79} \mathrm{Cf}$. BGH 26/08/2020, párr. 12.

${ }^{80} \mathrm{Cf}$. A. Colombi Ciacchi, "Internationales Privatrecht, ordre public européen und Europäische Grundrechte“, Zentrum für Europäische Rechtspolitik an der Universität Bremen (ed.), núm. 1, 2008. Cf. BVerfG 04/05/1971, párr. 67

${ }^{81}$ Cf. ibid.

${ }^{82}$ Ma . D. Ortiz Vidal, "El repudio en el Código de Familia de Marruecos y la aplicación del derecho marroquí en la UE", Cuadernos de Derecho Transnacional, vol. 6, núm. 2, 2014, pp. 201-244.

${ }^{83}$ Vid. Art. 4.3 TUE.
} 
comunidad europea "son el interés de los estados" $" 84$, teniendo en cuenta que los preceptos de los tratados internacionales pasan a formar parte del ordenamiento jurídico español ${ }^{85}$ y alemán ${ }^{86}$.

27. En cualquier caso, un tribunal nacional podrá invocar el orden público internacional en defensa de principios esenciales de la UE. Respecto al repudio islámico, destacan la prohibición de discriminación por razón de sexo del art. 21.1 Carta de los Derechos Fundamentales de la Unión Europea y el derecho a la tutela judicial efectiva conforme a los art. 47 y art. 6.1 Convención Europea de Derechos Humanos. Dichos valores crean un elemento común del orden público internacional de todos los Estados Miembros, ${ }^{87}$ sometido a una interpretación conforme a la jurisprudencia supra- e internacional ${ }^{88}$. Así pues, se limita el margen de discrecionalidad del juez nacional al aplicar el orden público internacional en defensa de dichos elementos.

\section{Postura del TJUE sobre sus competencias de control de orden público internacional}

\subsection{Idea preliminar}

28. El orden público internacional es un "concepto abierto e ilimitado pero limitable" 89 . Considerando su carácter nacional y el principio de respeto de las identidades nacionales ${ }^{90}$, el TJUE lo define como un conjunto de las reglas básicas establecidas por el estado soberano en defensa de sus intereses, cuya interpretación corresponde a cada Estado Miembro. ${ }^{91}$ Por el contrario, corresponde al TJUE establecer los límites a la aplicación del orden público internacional, ${ }^{92}$ porque pese a su aplicación por el juez nacional, constituyen normas de creación comunitaria. Para garantizar la armonía de sentencias en el plano internacional ${ }^{93}$, el orden público internacional sólo debe operar en defecto de medidas menos estrictas para alcanzar el mismo resultado ${ }^{94}$. En particular, las normas de conflicto del Derecho internacional europeo suelen ofrecer puntos de conexión alternativos que provocan la aplicabilidad de la lex fori para así evitar la invocación del orden público internacional ${ }^{95}$. Los límites de aplicación del orden público internacional son cada vez más estrictos. Así queda corroborado por los reglamentos celebrados a partir del año 2000 al exigir la concurrencia de una incompatibilidad manifiesta con el orden público internacional del foro, lo cual provocó un notable deceso en la utilización de la figur ${ }^{96}$.

${ }^{84}$ L.A. López ZAmora, "Comentarios sobre el Orden Público Internacional en sede arbitral internacional, su funcionalidad y su interrelación con el Derecho internacional público", Cuadernos de Derecho Transnacional, vol. 10, núm. 2, 2018, pp. 516-535.

${ }^{85}$ Vid. Art. 10.2 y 96.1 CE.

${ }^{86} \mathrm{Vid}$. Art. 35 y $59.2 \mathrm{GG}$.

${ }^{87}$ Cf. B. v. Hoffmann \& K. Thorn, "§6. Grundbegriffe: Ordre Public“, en B. v. Hoffmann \& K. Thorn (eds.), Internationales Privatrecht, 9a ed., C.H. Beck, Múnich, 2007, pp. 136-154.

${ }^{88} \mathrm{Cf}$. P. Scholz, "Grundfälle zum IPR: Ordre public - Vorbehalt und islamisch geprägtes Recht - Teil 1 (Allgemeiner Teil)“, Zeitschrift für das Juristische Studium, núm. 2, 2010, pp. 185-197.

${ }^{89}$ L.A. López ZAMORA, "Comentarios sobre el Orden Público Internacional en sede arbitral internacional, su funcionalidad y su interrelación con el Derecho internacional público", Cuadernos de Derecho Transnacional, vol. 10, núm. 2, 2018, pp. 516-535.

${ }^{90} \mathrm{Vid}$. art. 4.2 TUE.

${ }^{91}$ Cf. STJCE 14/3/2000, citada por M. Frey \& L. Pfeifer, „Der ordre public - die öffentliche Ordnung: derselbe Begriff, verschiedene Funktionen - ein Rechtsprinzip?“, Europarecht, vol. 50, núm. 6, 2015, pp. 721-734.

${ }^{92}$ Cf. A. Ybarra Bores, "Los problemas de aplicación del sistema de derecho internacional privado", en A. RodríGueZ BenOt et al. (ed.), Manual de derecho internacional privado, $6^{\text {a }}$ ed., Tecnos, Madrid, 2019, pp. 149-162.

${ }^{93} \mathrm{Cf}$. A. Colombi CiACCHI, "Internationales Privatrecht, ordre public européen und Europäische Grundrechte“, Zentrum für Europäische Rechtspolitik an der Universität Bremen (ed.), núm. 1, 2008.

${ }^{94} C f$. STJCE 14/3/2000, párr. 18.

${ }^{95} C f$. J. v. HeIn, "Internationales Privatrecht I - Allgemeiner Teil: Art. 6 EGBGB“, en F.J. SÄCKER et al. (ed.), Münchener Kommentar zum BGB, 8a ed., vol. 12, C.H. Beck, Múnich, 2020.

${ }^{96} \mathrm{Cf}$. A. Colombi Ciacchi, "Internationales Privatrecht, ordre public européen und Europäische Grundrechte“, Zentrum für Europäische Rechtspolitik an der Universität Bremen (ed.), núm. 1, 2008.

Cf. STJCE 14/3/2000, párr. 18. 


\subsection{El asunto Sahyouni}

29. Hay que partir de la idea contemplada en el art. 10 Reglamento (UE) 1259/2010 en el que se contiene una cláusula específica de orden público internacional para supuestos en los que la ley extranjera prevea el acceso desigual al divorcio para uno de los cónyuges por razón de su sexo.

Es cuestión controvertida aquellos divorcios en los que se materializa su consecución sin intervención judicial, tal y como sucede con ciertas clases del repudio. En ausencia de una definición exacta del concepto de "divorcio" al cual se refiere el art. 1 del mismo Reglamento, ${ }^{97}$ esta ha de ser concebido en las líneas marcada por el Alto Tribunal de Luxemburgo 98 .

Así, en los asuntos Sahyouni $I^{99}$ y Sahyouni $I^{100}$, el TJUE tuvo ocasión de pronunciarse acerca de la relación entre los "divorcios privados", el orden público internacional y el Reglamento (UE) $1259 / 2010$.

30. La situación sobre la que se sostienen se sitúa en el siguiente contexto. Un tribunal alemán conocía de una solicitud de reconocimiento de un repudio llevado a cabo por un varón sirio-alemán ante un tribunal religioso en Siria. Estimada la solicitud, la mujer repudiada solicitó la cancelación alegando una vulneración del orden público internacional alemán. Así las cosas, se plantea la cuestión prejudicial ante el TJUE, esencialmente sobre el alcance de la cláusula del art. 10 Reglamento (UE) 1259/2010 y su aplicabilidad a divorcios sin intervención judicial. Con anterioridad, el tribunal alemán había denegado la aplicabilidad de la cláusula general de orden público internacional regulada en el art. 12 del mismo Reglamento $^{101}$. En su respuesta, el TJUE se declaró manifiestamente incompetente argumentando que tal reglamento europeo versa sobre la ley aplicable a demandas de divorcio sin que sea aplicable a supuestos de reconocimiento de resoluciones de divorcio ${ }^{102}$. El tribunal alemán rectificó su cuestión sosteniendo que era práctica jurídica común en Alemania acudir a los requisitos sustantivos del Reglamento (UE) 1259/2010 para tramitar el reconocimiento de divorcios privados. ${ }^{103} \mathrm{La}$ implementación de dicha técnica se debe a que, tras la entrada en vigor del Reglamento, el legislador alemán había sustituido los preceptos nacionales relativos al reconocimiento con una remisión total a los preceptos comunitarios. No obstante, hemos de recordar que el Reglamento (CE) 2201/2003 ${ }^{104}$ no cubre las resoluciones provenientes de terceros estados, ${ }^{105}$ además del hecho de que el acto dictado por el tribunal religioso carece de efecto constitutivo, circunstancia que hubiera provocado la denegación del reconocimiento ante un tribunal español ${ }^{106}$.

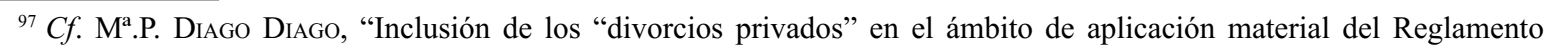
1259/2010 del Consejo, de 20 de diciembre de 2010”, La Ley Unión Europea, núm. 58, 2018.

${ }^{98} C f$. M ${ }^{\text {a }}$. D. Ortiz VIDAL, "El repudio en el Código de Familia de Marruecos y la aplicación del derecho marroquí en la UE”, Cuadernos de Derecho Transnacional, vol. 6, núm. 2, 2014, pp. 201-244.

${ }^{99}$ Vid. ATJUE 12/05/2016, ECLI:EU:C:2016:343.

${ }^{100}$ Vid. STJUE 20/12/2017, ECLI:EU:C:2017:988.

${ }^{101}$ Cf. C.M. CAAmiña Domínguez, "Divorcio privado dictado por un tribunal religioso de un tercer estado: asunto C-281/15, Soha Sahyouni y Raja Mamisch”, Cuadernos de Derecho Transnacional, vol. 9, núm. 2, 2017, pp. 629-634.

${ }^{102} C f$. ATJUE 12/05/2016, párr. 19.

${ }^{103}$ Cf. Ma .A. García Sellens \& C. Zimmer, „Reconocimiento y divorcios privados - Reflexiones a la luz del Auto del TJUE de 12 de mayo de 2016, asunto C-281/15, Sahyouni c. Mamisch”, Bitácora Millennium DIPr: Derecho Internacional Privado, núm. 4, 2016.

${ }^{104}$ Reglamento (CE) no 2201/2003 del Consejo, de 27 de noviembre de 2003, relativo a la competencia, el reconocimiento y la ejecución de resoluciones judiciales en materia matrimonial y de responsabilidad parental, por el que se deroga el Reglamento (CE) no 1347/2000 (DOUE núm. 338, de 23 de diciembre de 2003). Conviene poner de manifiesto que, el Reglamento (CE) 2201/2003 quedará derogado a partir del 1 de agosto de 2022 por el Reglamento (UE) 2019/1111 del Consejo, de 25 de junio de 2019, relativo a la competencia, el reconocimiento y la ejecución de resoluciones en materia matrimonial y de responsabilidad parental, y sobre la sustracción internacional de menores (DOUE L 178/1, de 2 de julio de 2019).

${ }^{105}$ Cf. C.M. CAamiña Domínguez, "Divorcio privado dictado por un tribunal religioso de un tercer estado: asunto C-281/15, Soha Sahyouni y Raja Mamisch”, Cuadernos de Derecho Transnacional, vol. 9, núm. 2, 2017, pp. 629-634.

${ }^{106} \mathrm{M}^{\mathrm{a}}$.A. García Sellens \& C. Zimmer, „Reconocimiento y divorcios privados - Reflexiones a la luz del Auto del TJUE de 12 de mayo de 2016, asunto C-281/15, Sahyouni c. Mamisch”, Bitácora Millennium DIPr: Derecho Internacional Privado, núm. $4,2016$. 
31. En su respuesta a la segunda cuestión prejudicial, el TJUE excluyó los divorcios privados del Reglamento (UE) 1259/2010, definiéndolos como divorcios sin intervención constitutiva de un órgano jurisdicciona ${ }^{107}$. De este modo, se puede plantear ciertas dudas en torno a si el TJUE es competente para interpretar las cláusulas de orden público internacional de los artículos 10 y 12 del Reglamento (UE) 1259/2010 a supuestos que excedan de su ámbito de aplicación. En principio, el TJUE está facultado para interpretar los preceptos comunitarios dentro de su ámbito de aplicación el cual corresponde a su marco competencial. Siguiendo esa lógica, la aplicabilidad del orden público internacional a materias no cubiertas por la norma europea correspondería a los Estados Miembros en exclusiva. No obstante, en el asunto Sahyouni II el TJUE se reservó la facultad interpretativa para "los casos en los que, a pesar de que los hechos del litigio principal no estén directamente comprendidos en el ámbito de aplicación del Derecho de la Unión, las disposiciones de este ordenamiento hayan sido declaradas aplicables por la legislación nacional, que se atiene, para resolver situaciones cuyos elementos están circunscritos al interior de un único Estado miembro, a las soluciones adoptadas por el Derecho de la Unión"108.

32. El TJUE defiende una interpretación uniforme de las cláusulas de orden público internacional, incluso cuando estas fueran aplicadas fuera del ámbito de aplicación. Permite a los Estados miembros complementar la laguna legal relativa al reconocimiento de divorcios privados por medio de una remisión "suficientemente precisa" 109 a los artículos 10 y 12 Reglamento (UE) 1259/2010 en la medida en que pretendan regular situaciones previstas por las disposiciones originarias ${ }^{110}$, esto es, comprobar la compatibilidad de la sentencia extranjera de divorcio con el orden público del foro, aunque sea mediante una cláusula de orden público de ley aplicable. Por lo contrario, el Estado miembro no está obligado a transponer la regulación sustantiva del Reglamento (UE) 1259/2010, ya que la competencia del TJUE "es sobre las situaciones o supuestos de hecho regulados y no sobre las técnicas empleadas"111. Ergo, el grado de intensidad del control de orden público internacional al cual se someta la decisión de divorcio tras repudio aún se determina por los Estados miembros. Así pues, a la hora de dar solución al divorcio sin intervención judicial, la doctrina española opta por una vía formal acudiendo al criterio de "imperium" mientras que la doctrina alemana prevé un "control de validez"112 con arreglo a los criterios propios de la ley aplicable. ${ }^{113}$ Siempre cuando se acudiese a los artículos 10 y 12 del Reglamento (UE) 1259/2010 ello implicaría una superposición de los requisitos del orden público internacional de ley aplicable y del orden público internacional de reconocimiento, caracterizándose ese último por su máxima excepcionalidad por motivo de la prohibición de revisión al fondo ${ }^{114}$.

\subsection{Perspectivas futuras alrededor de un orden público europeo aplicable a repudios}

33. El asunto Sahyouni demostró la insuficiencia de regulación del repudio y del divorcio privado por el Derecho internacional privado europeo. No resultando aplicable ni el Reglamento (UE) 1259/2010, ni el Reglamento (CE) 2201/2003, corresponde a los Estados miembros buscar una justa solución al "hueco Sahyouni". Debido a que los preceptos nacionales fueron derogados, los Estados miembros solamente podrán acudir a las cláusulas comunitarias de orden público por referencia.

\footnotetext{
${ }^{107} C f$. STJUE 20/12/2017, párr. 48.

${ }^{108}$ STJUE 20/12/2017, párr. 28.

${ }^{109}$ C.M. CAamiña Domínguez, "Divorcio privado dictado por un tribunal religioso de un tercer estado: asunto C-281/15, Soha Sahyouni y Raja Mamisch”, Cuadernos de Derecho Transnacional, vol. 9, núm. 2, 2017, pp. 629-634.

${ }^{110}$ STJUE 20/12/2017, párr. 28.

${ }^{111}$ S. Álvarez GonzÁlez, "Sahyouni más allá del espejo. Un comentario posible a la STJ de 20 de diciembre de 2017 (C372/16)" Revista Electrónica de Estudios Internacionales: Crónica de Derecho Internacional Privado, núm. 35, 2018, pp. 15-20.

${ }_{112}$ M$^{a}$.P. Diago Diago, “Inclusión de los “divorcios privados” en el ámbito de aplicación material del Reglamento 1259/2010 del Consejo, de 20 de diciembre de 2010”, La Ley Unión Europea, núm. 58, 2018.

${ }^{113} \mathrm{M}^{\mathrm{a}}$.A. García Sellens \& C. Zimmer, „Reconocimiento y divorcios privados - Reflexiones a la luz del Auto del TJUE de 12 de mayo de 2016, asunto C-281/15, Sahyouni c. Mamisch”, Bitácora Millennium DIPr: Derecho Internacional Privado, núm. 4, 2016.

${ }^{114}$ Vid. art. 26 BII-bis; art. 48 LCJIMC; § 109.5 FamFG.
} 
La incertidumbre provocada por la exclusión del divorcio privado del Reglamento (UE) 1259/2010 podría motivar a los Estados miembros formular remisiones a textos comunitarios bajo reservas lo que podría crear un doble régimen ${ }^{115}$ susceptible de perjudicar los objetivos del propio Reglamento (UE) 1259/2010.

34. El orden público internacional está impregnado por un proceso de fragmentación ${ }^{116}$ siendo recogido puntualmente en diversos textos comunitarios. Existen voces a favor de una codificación comunitaria del orden público internacional ${ }^{117}$.

Un "orden público internacional europeo" garantizaría su uso uniforme en todos los Estados miembros; si bien, todavía correspondería a los tribunales nacionales invocarlo, los requisitos y su contenido se fijarían por la cláusula europea general. En ese sentido, el art. 10 del Reglamento (UE) $1259 / 2010$ puede ser considerado prototipo de una cláusula europea de orden público internacional ${ }^{118}$, pues contiene un valor esencial cuya protección se considera imprescindible en la UE. Además, crea una priorización de dicho elemento frente al resto de elementos del orden público nacional e incrementa la frecuencia del uso del orden público internacional en su favor. El TJUE ya no interpreta tan sólo los límites del art. 10, sino también el alcance del principio de igualdad, dado que no existe una comprensión unitaria y neutra de los derechos fundamentales, podrían surgir tensiones ${ }^{119}$.

35. Sin embargo, el carácter hibrido de las cláusulas comunitarias de orden público internacional obstaculiza el desarrollo doctrinal de un "orden público internacional europeo" porque su aplicación siempre se lleva a cabo ante los tribunales nacionales ${ }^{120}$. Estos realizan un mero control de resultado, por lo que la ocupación con el orden público internacional queda limitada al examen de compatibilidad en supuestos individuales. De hecho, resulta irrelevante si una cláusula de orden público tiene carácter formal comunitario o nacional porque en ambos casos su contenido es idéntico. Es decir, constituye una superposición de principios esenciales de origen nacional y de valores comunitarios a cuya salvaguarda se comprometen los Estados miembros. Debido al carácter erga omnes del Reglamento (UE) 1259/2010 es preciso obtener un mayor conocimiento del derecho islámico frecuentemente aplicable y desarrollar criterios que posibilitan su homologación con el divorcio ${ }^{121}$.

Por ello, convendría una jurisprudencia europea que comparte las respectivas experiencias y prácticas de todos los Estados miembros. Dado que un orden público internacional europeo "puro" todavía no parece probable, el mismo efecto podría alcanzarse a través de un aumento del uso de la cuestión prejudicial.

\section{La compleja tarea de homologación del repudio}

\section{Delimitación entre Talaq, repudio y divorcio}

36. El Talaq constituye el conjunto de causas de ruptura del vínculo matrimonial "con arreglo a las reglas de origen divino contempladas en la Sharia, tal y como han sido desarrolladas por las reglas fijadas por cada una de las tradiciones ideológicas islámicas que se han plasmado, a su vez, en dispo-

${ }^{115}$ Cf. S. Álvarez González, "Sahyouni más allá del espejo. Un comentario posible a la STJ de 20 de diciembre de 2017 (C-372/16)" Revista Electrónica de Estudios Internacionales: Crónica de Derecho Internacional Privado, núm. 35, 2018, pp. $15-20$.

${ }^{116} C f$. J. v. Hein, "Internationales Privatrecht I - Allgemeiner Teil: Art. 6 EGBGB“, en F.J. SÄCKER et al. (ed.), Münchener Kommentar zum BGB, 8a ed., vol. 12, C.H. Beck, Múnich, 2020.

${ }^{117}$ Cf. ibid.

${ }^{118}$ Cf. ibid.

${ }^{119}$ Cf. ibid.

${ }^{120}$ Cf. ibid.

${ }^{121} C f$. M . D. Ortiz Vidal, "El repudio en el Código de Familia de Marruecos y la aplicación del derecho marroquí en la UE”, Cuadernos de Derecho Transnacional, vol. 6, núm. 2, 2014, pp. 201-244. 
siciones legislativas islámicas de origen estatal" ${ }^{122}$. Dentro del Talaq, el repudio representa una causa particular de disolución del matrimonio por voluntad de un cónyuge o por mutuo acuerdo ${ }^{123}$.

Si bien, los tribunales alemanes incurren en el error de equiparar el repudio con el Talaq ${ }^{124}$. De igual manera, es fácil hallar tal situación ante los tribunales españoles ${ }^{125}$ aunque en la mayoría de los casos simplemente se acude al término repudio ${ }^{126}$.

37. El repudio es una institución sólo parcialmente desconocida ${ }^{127}$ para los sistemas jurídicos europeos, porque igual que el divorcio despliega una función disolutiva del vínculo matrimonial, homologándose a través de una calificación por función. La regulación del repudio es tan diversa cómo la del divorcio. La predominante tradición ideológica sunita se divide en cuatro escuelas jurídicas entre las cuales existen discrepancias relativas a su contenido, requisitos y alcance ${ }^{128}$. A su vez, las interpretaciones del repudio se desarrollan de manera distinta en los sistemas jurídicos inspirados en el derecho islámico. Suele regularse en la ley sobre el estatuto personal, así verbi gratia, en Egipto, Marruecos, Iraq y Kuwait ${ }^{129}$. No obstante, existen otros estados como Turquía o Túnez donde el repudio no está admitido $^{130}$.

38. Como rasgo en común, el repudio se lleva a cabo mediante la pronunciación de una fórmula, oral o escrita, que pone de manifiesto la intención inequívoca de querer repudiar al cónyuge, en presencia de dos testigos varones, púberes y musulmanes ${ }^{131}$. La capacidad del sujeto activo se somete a criterios equivalentes a aquellos exigidos para la celebración del matrimonio, tales como la salud mental y la ausencia de coacción ${ }^{132}$. Entre los efectos comunes a toda clase de repudio, destaca la haddana, la custodia de los hijos impúberes concedida a la mujer. También conviene aclara que, la mahr consiste en la devolución total o parcial de la dote en casos de repudio arbitrario por parte del varón.

\section{Rasgos problemáticos del repudio}

\subsection{Revocabilidad}

39. No todo repudio es revocable. El Talaq al-sunna prevé una o tres pronunciaciones de la fórmula talaq durante el periodo de pureza $(t u h r)$ de la mujer ${ }^{133}$. Durante las dos primeras pronunciaciones, el vínculo matrimonial subsiste con efectos suspensivos ${ }^{134}$. Se abre un periodo de reflexión (idda)

${ }^{122}$ S. Pérez Álvarez, "Las tradiciones ideológicas islámicas ante el repudio. Su eficacia civil en el derecho del estado español”, Ilu. Revista de Ciencia de las Religiones, núm. 13, 2008, pp. 183-223.

${ }^{123} C f$. M. Mut Bosque et al., "Reflexiones sobre el repudio islámico y judío en el derecho civil y penal español: la institución del orden público internacional: Vol. II International Conference Family and Society”, 2015.

${ }^{124}$ Vid. OLG Hamm 11/10/2010; OLG Stuttgart 03/05/2019.

${ }^{125}$ Vid. SAP Murcia 12/05/2003; SAP Barcelona, 10/09/2019.

126 Vid. SAP Cáceres 23/05/2012; AAP Málaga 29/01/2015.

${ }^{127} \mathrm{M}^{\mathrm{a}}$. D. OrTiz VidAL, "El repudio en el Código de Familia de Marruecos y la aplicación del derecho marroquí en la UE", Cuadernos de Derecho Transnacional, vol. 6, núm. 2, 2014, pp. 201-244.

${ }^{128}$ Cf. S. Pérez Álvarez, "Las tradiciones ideológicas islámicas ante el repudio. Su eficacia civil en el derecho del estado español”, Ilu. Revista de Ciencia de las Religiones, núm. 13, 2008, pp. 183-223.

${ }^{129}$ Cf. ibid.

${ }^{130} C f$. H. Agullar Grieder, "Multiculturalidad, reconocimiento en España de repudios islámicos pronunciados en el extranjero y actuales tendencias del orden público en el D.I.Pr.", Cuestiones actuales de derecho comparado: actas de las reuniones académicas celebradas el 13 de julio de 2001 y el 10 de octubre de 2002 en la Facultad de Derecho de A Coruña, 2003, pp. 235-264.

${ }^{131}$ Cf. ibid.

${ }^{132}$ Cf. S. Pérez Álvarez, "Las tradiciones ideológicas islámicas ante el repudio. Su eficacia civil en el derecho del estado español”, Ilu. Revista de Ciencia de las Religiones, núm. 13, 2008, pp. 183-223.

${ }^{133} C f$. Ma . D. Ortiz Vidal, "El repudio en el Código de Familia de Marruecos y la aplicación del derecho marroquí en la UE”, Cuadernos de Derecho Transnacional, vol. 6, núm. 2, 2014, pp. 201-244.

${ }^{134} C f$. M. Mut Bosque et al., "Reflexiones sobre el repudio islámico y judío en el derecho civil y penal español: la institución del orden público internacional: Vol. II International Conference Family and Society”, 2015. 
de aproximadamente tres meses durante la cual la mujer permanece en el domicilio conyugal y obtiene alimentos, siéndole imposible la contratación de segundas nupcias. Durante dicha fase, que tiene como finalidad la determinación de paternidad en el caso de un embarazo, es posible retomar la convivencia conyugal sin efectos para el vínculo matrimonial ${ }^{135}$.

Por lo contrario, el Talaq al-bid 'a consiste en la triple pronunciación consecutiva de la fórmula (talaq, talaq, talaq) y da lugar a la disolución inmediata del matrimonio ${ }^{136}$. Esa modalidad del repudio ha sido derogada en muchos estados con legislación islámica ${ }^{137}$.

40. No obstante, el carácter revocable del repudio tendrá un doble significado: Por un lado, es incompatible con el principio de seguridad jurídica, integrante del orden poúblico internacional español ${ }^{138}$ y alemán ${ }^{139}$. La facultad de revocar la disolución del matrimonio genera "una inestabilidad muy profunda del estado civil, lo que puede perjudicar a terceros y a la sociedad española en su conjunto"140. También, tiene carácter discriminatorio, porque a diferencia del repudio, el divorcio instado por la mujer tiene siempre efectos irrevocables ${ }^{141}$. Por otro lado, en el ámbito de reconocimiento de actos la revocabilidad constituye un motivo por el cual el orden público internacional no llega a ser apreciado ${ }^{142}$.

\subsection{Unilateralidad}

41. Mientras que "el repudio clásico es unilateral, discriminatorio y privado"143, también existe una vía por medio de la cual la mujer puede instar la disolución del vínculo matrimonial $(k h u l)$. En ese caso, la mujer solicita a la autoridad que el varón la repudie en cambio a una indemnización pecuniaria $^{144}$. Estimada la solicitud, el juez se subroga en la posición del varón y pronuncia el repudio. Bajo ciertas condiciones, la indemnización no es necesaria, como, por ejemplo, cuando el varón haya concedido a la mujer la facultad de repudiarle contractualmente ${ }^{145}$.

\subsection{Ausencia de intervención judicial}

42. No todo repudio equivale a un divorcio privado. En muchos estados con tradición islámica se observa un proceso hacia la "procesionalización" del repudio, a través de su legalización mediante decreto judicial (Iraq), acta notarial (Egipto), certificado emitido por el registrador civil (Líbano) o acta emitida por dos adules presentes (Marruecos) ${ }^{146}$.

\footnotetext{
${ }^{135}$ Cf. ibid.

${ }^{136}$ Cf. S. S. Pérez Álvarez, "Las tradiciones ideológicas islámicas ante el repudio. Su eficacia civil en el derecho del estado español”, Ilu. Revista de Ciencia de las Religiones, núm. 13, 2008, pp. 183-223.

${ }^{137}$ Cf. S. Rutten, "Recognition of Divorce by Repudiation (talaq) in France, Germany and the Netherlands", Maastricht Journal of European and Comparative Law, vol. 11, núm. 3, 2004, pp. 263-285.

${ }^{138}$ Vid. Art. $9.3 \mathrm{CE}$.

${ }^{139}$ Vid. BVerfG 01/07/1953, FJ II.2.

${ }^{140}$ A.L. Calvo Caravaca \& J. Carrascosa González, "Crisis matrimoniales", en A.L. Calvo Caravaca \& J. Carrascosa GonZÁlez (eds.), Derecho Internacional Privado: Vol. II, $18^{\mathrm{a}}$ ed., Comares, Granada, 2018, pp. 227-314.

${ }^{141}$ Vid. SAP La Rioja 07/04/2014, FJ. 2.

142 Vid. párr. 64.

${ }^{143}$ A.L. Calvo Caravaca \& J. Carrascosa González, "Crisis matrimoniales”, en A.L. Calvo Caravaca \& J. Carrascosa GonzÁlez (eds.), Derecho Internacional Privado: Vol. II, $18^{a}$ ed., Comares, Granada, 2018, pp. 227-314.

${ }^{144} C f$. S. Pérez Álvarez, "Las tradiciones ideológicas islámicas ante el repudio. Su eficacia civil en el derecho del estado español”, Ilu. Revista de Ciencia de las Religiones, núm. 13, 2008, pp. 183-223.

${ }^{145} \mathrm{Cf}$. A.L. Calvo Caravaca \& J. Carrascosa González, "Crisis matrimoniales", en A.L. Calvo Caravaca \& J. CarrascoSA González (eds.), Derecho Internacional Privado: Vol. II, 18ª ed., Comares, Granada, 2018, pp. 227-314.

${ }^{146}$ Cf. S. Pérez Álvarez, "Las tradiciones ideológicas islámicas ante el repudio. Su eficacia civil en el derecho del estado español”, Ilu. Revista de Ciencia de las Religiones, núm. 13, 2008, pp. 183-223.
} 
Por otro lado, el repudio sigue surtiendo efectos sin intervención de autoridad ninguna en Yemen, Kuwait, Saudí Arabia y Siria ${ }^{147}$. La diversidad de la figura impide el desarrollo de una jurisprudencia reiterada por los tribunales europeos y dificulta su calificación cómo acto privado, público o judici ${ }^{148}$.

En ambos estados, la ausencia de intervención judicial choca con el orden público internacional ${ }^{149}$, pues en Alemania ${ }^{150}$ y España, ${ }^{151}$ la disolución del matrimonio corresponde en exclusiva al estado. Su intervención garantiza el ajuste del divorcio a la ley. ${ }^{152}$ Es más, un acto que carece de intervención estatal no podrá ser calificado como objeto de examen en el ámbito de reconocimiento de resoluciones extranjeras ${ }^{153}$.

\section{El orden público internacional en sede de ley aplicable. Análisis comparativo del enfoque espa- ñol y alemán}

\section{Vulneración del principio de igualdad}

43. Los tribunales alemanes y españoles que se enfrentan a un repudio coinciden con que "la discriminación por razón del sexo resulta evidente"154. El BGH estima que el repudio clásico unilateral vulnera el principio de igualdad entre hombre y mujer a tenor del art. 3.2 GG, pues la mujer queda reducida a un mero objeto del divorcio, a disposición del varón como protagonista del proceso ${ }^{155}$.

En esa misma línea, el TS sostiene que "la legislación islámica ha puesto por regla general el repudio en manos del esposo" ${ }^{156}$, lo que contradice al principio de igualdad conyugal de los art. 14 y 32.1 CE.

44. Con arreglo al principio de primacía del derecho europeo, se debe acudir primeramente a las cláusulas comunitarias de orden público internacional. No obstante, la asunción errónea del legislador español y alemán de que Reglamento (UE) 1259/2010 incluía los divorcios privados provocó el "Hueco Sahyouni" 157 . Fundado sector doctrinal, considera que la remisión incondicionada al Reglamento (UE) 1259/2010 por ambos países es "un tanto aventurada"158. A diferencia de la remisión total del art. 17.2 EGBGB, el art. 107 CC contiene una remisión alternativa: "La separación y el divorcio legal se regirán por las normas de la Unión Europea o españolas de Derecho internacional privado".

45. Así pues, tanto el art. 17.2 EGBGB y el art. 107.2 CC contienen una "remisión a la nada" ${ }^{159}$. Ahora bien, ¿Cómo se rellenó el "Hueco Sahyouni" en España y Alemania y qué consecuencias se derivan para el uso del orden público internacional frente al repudio?

46. El TJUE admite que los Estados miembros "nacionalicen" preceptos sustantivos del Reglamento (UE) 1259/2010 para regular asuntos excluidos de su ámbito de aplicación ${ }^{160}$. El legislador

${ }^{147}$ Cf. S. Rutten, "Recognition of Divorce by Repudiation (talaq) in France, Germany and the Netherlands", Maastricht Journal of European and Comparative Law, vol. 11, núm. 3, 2004, pp. 263-285.

${ }^{148}$ Cf. ibid.

${ }^{149} C f$. AG Kulmbach 28/10/2003, p.2.

${ }^{150}$ Vid. art. 17.3 EGBGB; § 1564 S.1 BGB.

${ }^{151} \mathrm{Cf}$. art. $89 \mathrm{CC}$; art. $117.3 \mathrm{CE}$.

${ }^{152}$ Cf. A.L. Calvo Caravaca \& J. Carrascosa González, "Crisis matrimoniales", en A.L. Calvo Caravaca \& J. CarrascoSA GonzÁlez (eds.), Derecho Internacional Privado: Vol. II, 18ª ed., Comares, Granada, 2018, pp. 227-314.

153 Vid. párr. 63.

${ }^{154}$ SAP La Rioja 07/04/2014, FJ. 2.

${ }^{155} C f$. BGH 26/08/2020, párr. 52.

${ }^{156}$ STS 25/01/2006, FJ 5.

${ }^{157}$ Vid. párr. $31-32$.

${ }^{158}$ S. Álvarez GonzÁlez, "Sahyouni más allá del espejo. Un comentario posible a la STJ de 20 de diciembre de 2017 (C372/16)" Revista Electrónica de Estudios Internacionales: Crónica de Derecho Internacional Privado, núm. 35, 2018, pp. 15-20.

${ }^{159}$ Ibid.

${ }^{160}$ Vid. párr. 32. 
alemán hizo uso de esa facultad, modificando el art. 17.2 EGBGB en enero de 2019. En principio, remite a los puntos de conexión de los art. 5 - 8 del Reglamento (UE) 1259/2010. No obstante, no se pretendía una aplicabilidad análoga de la norma comunitaria a los divorcios privados ${ }^{161}$. En todo caso, el art. 17.2.5 excluye expresamente la aplicabilidad de las cláusulas de orden público internacional de los artículos 10 y 12 del Reglamento (UE) 1259/2010 y remite a su vez al art. 6 EGBGB. Como consecuencia, el repudio se rige por la cláusula general de orden público internacional, con efectos retroactivos desde la entrada en vigor del Reglamento (UE) 1259/2010. ${ }^{162}$ En base a la frase segunda del art. 6 EGBGB, los tribunales alemanes invocan rigurosamente el art. 3.2 GG, mientras vacilan a la hora de citar preceptos internacionales que recojan el principio de igualdad ${ }^{163}$.

47. Por otro lado, el legislador español todavía no ha corregido la remisión viciosa del art. 107.2 $\mathrm{CC}$ y algún autor teme que tampoco procederá a hacerlo ${ }^{164}$. En su defecto, la doctrina española entiende que la remisión del art. 107.2 debe interpretarse en el sentido de que supone una "nacionalización"165 de los preceptos reglamentarios, por lo que serían aplicables los preceptos sustantivos "por referencia", esto es, más allá de su ámbito de aplicación europeo ${ }^{166}$. Así pues, se aplicará al repudio la segunda alternativa del art. 10 Reglamento (UE) 1259/2010 cómo lex specialis frente al art. 12. El art. 10 hace referencia al principio de la igualdad de sexo, recogido en el art. 21.1 de la Carta de los Derechos Fundamentales. A partir de la entrada en vigor del Reglamento (UE) 1259/2010, los tribunales españoles invocaron los preceptos fundamentales comunitarios de manera encomiable. Manifiesto de ello, se puede observar en la SAP La Rioja de 7 de abril de 2014, en la que se activa el art. 10 Reglamento (UE) 1259/2010 contra un repudio con referencia al art. 21.1 Carta de los Derechos Fundamentales y sin mención de los artículos 14 y 32.1 de la Constitución española. Ello es destacable teniendo en cuenta el carácter híbrido de las cláusulas comunitarias de orden público internacional, pues nada impide al tribunal español invocar sus preceptos nacionales con basamento en la norma europea.

\section{Intensidad de la incompatibilidad}

48. El Derecho internacional privado se rige por los principios de igualdad y tolerancia frente a instituciones jurídicas desconocidas ${ }^{167}$. Por ello, no basta con la mera diferencia de resultados según lex fori y ley extranjera ${ }^{168}$.

En esa línea, la jurisprudencia de ambos países vela por el carácter restrictivo del orden público internacional "clásico" para evitar situaciones claudicantes que no serán reconocidas en el estado de origen de los litigantes ${ }^{169}$.

49. No obstante, ello no tiene injerencia en relación con el repudio. Así, el art. 10 Reglamento (UE) 1259/2010, aplicable por referencia en España, no indica ningún grado de intensidad del carácter discriminatorio, pues carece del término manifiesto. Tal y como ocurre con la frase segunda del art. 6 EGBGB, su falta crea la presunción de que una vulneración de los art. 21 Carta de los Derechos Fundamentales de la UE o art. 3.2 GG implica siempre una incompatibilidad manifiesta. La jurisprudencia alemana se limita a confirmar la vigencia del derecho fundamental afectado en supuestos de tráfico

${ }^{161} C f$. BGH 26/08/2020, párr.9.

${ }^{162}$ Cf. ibid., párr. 29.

163 Vid. e.g. ibid., párr. 52.

${ }^{164}$ Cf. S. Álvarez GonzÁlez, "Sahyouni más allá del espejo. Un comentario posible a la STJ de 20 de diciembre de 2017 (C372/16)" Revista Electrónica de Estudios Internacionales: Crónica de Derecho Internacional Privado, núm. 35, 2018, pp. 15-20.

${ }^{165}$ A.L. Calvo Caravaca \& J. Carrascosa González, "Crisis matrimoniales", en A.L. Calvo Caravaca \& J. Carrascosa GonZÁlez (eds.), Derecho Internacional Privado: Vol. II, $18^{\mathrm{a}}$ ed., Comares, Granada, 2018, pp. 227-314.

166 Ibid.

${ }^{167} C f$. M.P. WelLER et al., „Gleichstellung im Internationalen Scheidungsrecht - talaq und get im Licht des Art. 10 Rom III-VO“, Praxis des Internationalen Privat- und Verfahrensrechts (IPRax), 2016, pp. 123-132.

${ }^{168}$ Vid. párr. 14 y 21.

${ }^{169}$ Cf. BGH 26/08/2020, párr. 52; SAP La Rioja 07/04/2014, FJ 2.; SAP Cáceres 23/05/2012, FJ 2. 
externos ${ }^{170}$. Por lo tanto, siempre cuando sea vea afectado el principio de igualdad, tanto el precepto alemán como el art. 10 Reglamento (UE) 1259/2010 por referencia presuponen una incompatibilidad manifiesta con el orden público internacional.

\section{3. Ámbito de control}

50. Los artículos $12.3 \mathrm{CC}$ y art. 6 EGBGB disponen que la solución ofrecida por la ley extranjera debe resultar incompatible con el orden público internacional. ${ }^{171}$ En Alemania, la jurisprudencia aplica de modo unánime la Ergebniskontrolle, criterio tácito que exige la incompatibilidad del resultado concreto tras aplicar la ley extranjera, ${ }^{172}$ aun cuando sean afectados los derechos fundamentales con arreglo la frase segunda del art. 6 EGBGB ${ }^{173}$ En esa misma línea, el TS rechaza la "genérica afirmación del carácter discriminatorio de una ley extranjera reguladora del divorcio y exige motivos concretos que fundamentan una discriminación ${ }^{174}$. El orden público español clásico busca "conseguir la justicia material del caso concreto, esto es, un resultado materialmente justo"175.

51. No obstante, la polémica alrededor del novedoso art. 10 del Reglamento (UE) 1259/2010, aplicable por referencia en España, pone en cuestión si la doctrina del control de resultado tiene validez en relación con el repudio.

Es incierto si el carácter discriminatorio al cual se refiere el art. 10 debe ser interpretado en un sentido abstracto o concreto. Si el art. 10 constituyese una cláusula especial de orden público internacional, sería transferible el principio de control de resultado, exigiéndose una infracción del principio de igualdad en el caso individual. Por el contrario, si el art. 10 fuese una norma de colisión, bastaría con la comprobación del tenor discriminatorio de la ley extranjera, sin necesidad de acreditar un perjuicio concreto ${ }^{176}$.

Sea como fuere, corresponde al TJUE la interpretación del precepto incluso fuera de su ámbito de aplicación ${ }^{177}$. No obstante, ha de ponerse de manifiesto que, en el asunto Sahyouni no llegó a pronunciarse sobre el alcance del art. 10, por lo que la decisión sobre el carácter abstracto o concreto aún queda pendiente ${ }^{178}$.

Ciertamente, el legislador alemán excluyó la aplicación del art. 10 y remitió al art. 6 EGBGB, manteniendo el control de resultado. Por lo contrario, el legislador español todavía no ha reaccionado. En verdad, no existen sentencias españolas relativas al repudio y posteriores a la decisión Sahyouni que pudieran definir el alcance del art. 10 del Reglamento (UE) 1259/2010 "nacionalizado"

52. En el ámbito doctrinal, algunos autores definen el art. 10 como "cláusula de rechazo"179 ya que constituye un mecanismo legal distinto ${ }^{180}$ a la clásica excepción de Derecho internacional privado.

\footnotetext{
${ }^{170}$ Vid. e.g. OLG Zweibrücken 16/11/2001, p.2.

${ }^{171} \mathrm{Vid}$. párr. 16 y 19.

${ }^{172}$ Cf. BGH 26/08/2020, párr. 53; BGH 06/10/2004, FJ 1.4; BGH 18/06/1970, FJ 3 c).

${ }^{173} C f$. E. JAYME, "Methoden der Konkretisierung des ordre public im Internationalen Privatrecht", JuRistische StudiengeSellschaft Karlsruhe (ed.), núm. 183, C.F. Müller Juristischer Verlag, Heidelberg, 1985.

${ }^{174} C f$. SAP Cáceres 23/05/2012, FJ 3.

${ }^{175}$ H. Aguilar Grieder, "Multiculturalidad, reconocimiento en España de repudios islámicos pronunciados en el extranjero y actuales tendencias del orden público en el D.I.Pr.", Cuestiones actuales de derecho comparado: actas de las reuniones académicas celebradas el 13 de julio de 2001 y el 10 de octubre de 2002 en la Facultad de Derecho de A Coruña, 2003, pp. 235-264.

${ }^{176}$ Cf. A.L. Calvo Caravaca \& J. Carrascosa González, "La ley aplicable al divorcio en Europa: El futuro Reglamento Roma III”, Cuadernos de Derecho Transnacional, vol. 1, núm. 1, 2009, pp. 36-71.

177 Vid. párr. 31.

${ }^{178} C f$. P. Winkler v. Mohrenfels, "Internationales Privatrecht I - Internationales Familienrecht: Art. 10 Rom III-VO“, en F.J. SäCKER et al. (ed.), Münchener Kommentar zum BGB, 8ª ed., vol. 12, C.H. Beck, Múnich, 2020.

179 Cf. A.L. Calvo Caravaca \& J. Carrascosa González, "Crisis matrimoniales", en A.L. Calvo Caravaca \& J. CarrascoSA GonzÁlez (eds.), Derecho Internacional Privado: Vol. II, $18^{\mathrm{a}}$ ed., Comares, Granada, 2018, pp. 227-314.

${ }^{180} \mathrm{Cf}$. J. CARrascosa GonzÁLez, "La ley aplicable al divorcio y la elegancia de la norma de conflicto. Apostillas a la sentencia del Tribunal de Justicia de la Unión Europea de 16 julio 2020”, Cuadernos de Derecho Transnacional, vol. 13, núm. 1, 2021, pp. 741-754.
} 
Esto es, el art. 10 proporciona "un modo más directo, automático y veloz para descartar, en casos muy graves, la aplicación de la ley extranjera, ya que no exige comprobar que, en el caso concreto, se produce vulneración del orden público internacional" ${ }^{\prime 181}$. A mayor abundamiento, el sentido literal del art. 10 sugiere un control abstracto del contenido de la ley extranjera ${ }^{182}$. Incluso, el considerando 24 del del Reglamento (UE) 1259/2010 establece que el art. 10 debe entenderse sin perjuicio de la cláusula relativa al orden público. La dualidad de los art. 10 y 12 no es casual: el legislador pretendía crear un mecanismo sui iuris en el espíritu del orden público internacional, pero con algunas diferencias ${ }^{183}$. A sensu contrario, otro sector sostiene que, el art. 10 constituye una cláusula de orden público internacional específica ${ }^{184} \mathrm{El}$ art. 10 se denomina "cláusula española" porque fue inspirado en el antiguo art. 107.2 $\mathrm{CC}^{185}$. Este se interpretaba por los tribunales españoles cómo "manifestación específica y concreta" 186 de la cláusula general del art. 12.3 $\mathrm{CC}$, destinado a "completar y dar adecuada protección jurídica a aquellas situaciones que, bajo el amparo de ordenamientos basados en tradiciones ajenas a la occidental, encubrían una discriminación"187. Los riesgos del "automatismo de esta regla" 188 se conocían, por lo que el art. 10, igual que el antiguo art. 107.2 $\mathrm{CC}$, debería ser interpretado en un sentido concreto para evitar situaciones claudicantes. El art. 10 funciona igual que una cláusula de orden público internacional, inactivando la ley convocada por las normas de conflicto de RRIII, lo cual justificaría aplicar el principio de control de resultado como límite a ese mecanismo.

53. Mientras que la remisión al art. 6 EGBGB aseguró la aplicabilidad del control de resultado al repudio en Alemania, es incierto si este criterio podrá ser mantenido por los tribunales españoles al aplicar el art. 10 del Reglamento (UE) 1259/2010 por referencia. Debido a que el antiguo art. 107.2 CC fue calificado cómo cláusula de orden público internacional específica, es probable que los tribunales españoles acudan a esa interpretación del 10 del Reglamento (UE) 1259/2010 "nacionalizado", manteniendo el control del resultado.

Al contrario, todo indica que el TJUE velará por una interpretación abstracta del precepto. Así lo sugiere el abogado general a colación del asunto Sahyouni ${ }^{189}$. Particularmente en relación con el repudio urge más claridad porque los tribunales llegan a soluciones divergentes según el caso concreto. En la mayoría de los casos, es la mujer la que solicita el divorcio contra la voluntad del varón, pero este se opone alegando la aplicabilidad de la ley extranjera que no prevé la disolución del matrimonio a instancia de la mujer ${ }^{190}$.

54. En ambos países, el hecho de que la mujer consienta no implica la aceptación de la forma prevista por la ley extranjera, que se caracteriza por su acceso desigual y la exigencia de alegar causas tasadas que convierten el matrimonio en fácticamente indisoluble a instancia de la mujer ${ }^{191}$. En España, la doctrina ha sido influenciada particularmente por el $k h u l^{192}$ marroquí. Este no se considera una vía verdaderamente bilateral, por tres motivos: $i$ ) Es preciso que la mujer alegue una causa, requisito que no se exige al hom-

${ }^{181}$ A.L. Calvo Caravaca \& J. Carrascosa González, "La ley aplicable al divorcio en Europa: El futuro Reglamento Roma III", Cuadernos de Derecho Transnacional, vol. 1, núm. 1, 2009, pp. 36-71.

${ }^{182} C f$. P. Winkler v. Mohrenfels, "Internationales Privatrecht I - Internationales Familienrecht: Art. 10 Rom III-VO“, en F.J. SÄcker et al. (ed.), Münchener Kommentar zum BGB, 8 ed., vol. 12, C.H. Beck, Múnich, 2020.

${ }^{183}$ Cf. ibid.

${ }^{184}$ Cf. B. Campuzano Díaz, "El Reglamento (UE) N. ${ }^{\circ}$ 1259/2010, de 20 de diciembre de 2010, por el que se establece una cooperación reforzada en el ámbito de la ley aplicable al divorcio y a la separación judicial”, Revista de Derecho Comunitario Europeo, núm. 39, 2011, pp. 561-587.

${ }^{185}$ Cf. ibid.

${ }^{186}$ SAP Cáceres 23/05/2012, FJ 2.

${ }^{187}$ SAP Barcelona 12/07/2003, FJ 2.

${ }^{188}$ B. Campuzano Díaz, "El Reglamento (UE) N. ${ }^{\circ}$ 1259/2010, de 20 de diciembre de 2010, por el que se establece una cooperación reforzada en el ámbito de la ley aplicable al divorcio y a la separación judicial", Revista de Derecho Comunitario Europeo, núm. 39, 2011, pp. 561-587.

${ }_{189} \mathrm{Vid}$. Conclusiones del abogado general Saugmansgaard Øe, Asunto C-372/16 (Soha Sahyouni contra Raja Mamisch), 2017, párr. 72.

${ }^{190}$ Vid. SAP La Rioja 07/04/2014; SAP Barcelona 19/07/2013; OLG Hamm 11/10/2010; BGH 06/10/2004.

${ }^{191} C f$. OLG Zweibrücken 16/11/2001, p.2; SAP La Rioja 07/04/2014, FJ. 2; OLG Hamm 11/10/2010, p. 2.

192 Vid. párr. 41. 
bre en los casos de repudio, ${ }^{193}$ ii) El $k h u l$ se resuelve siempre mediante procedimiento judicial y no llega a surtir efectos irrevocables antes del pronunciamiento, ${ }^{194}$ iii) La mujer que insta el khul debe compensar al marido, p. ej. mediante la renuncia al pago de alimentos o a la devolución de la dote por el varón ${ }^{195}$. En estos supuestos, el consentimiento de la mujer no subsana el carácter discriminatorio de la ley extranjera.

No obstante, en determinados supuestos en los que la mujer desea divorciarse mediante repudio, el BGH sostiene que su voluntad subsana la incompatibilidad con el orden público internacional, gozando la mujer de autonomía plena para decidir sobre la forma externa de su divorcio ${ }^{196}$. Si los cónyuges quieren divorciarse y eligen la forma del repudio como opción más económica, ágil o favorable para la mujer, el orden público internacional no debería activarse. En España, dicho motivo económico subsana el carácter discriminatorio, sin perjuicio de que la facultad de divorciarse sea condicionada al abono de una compensación económica ${ }^{197}$. En cambio, en Alemania, la manifestación del consentimiento se somete a criterios rigurosos, dado que tiene que ser expreso ${ }^{198}$ y cubrir todo aspecto del repudio, no vale la mera aceptación de una compensación económica ${ }^{199}$.

Así las cosas, resulta casi imposible que la repudiada consienta en el trato discriminatorio, siendo probable la activación del orden público internacional ${ }^{200}$. No obstante, su rigor se atenúa mediante otro criterio de control de resultado propio del sistema alemán. A diferencia de España, dónde el matrimonio podrá ser disuelto directamente cuando haya durado tres meses (art. $81 \mathrm{CC}$ ), en Alemania rige el Zerrüttungsprinzip, una presunción iuris et de iure de ruptura del matrimonio cuando los cónyuges hayan vivido por separado durante al menos un año, $\S \S 1565,1566$ I BGB. Es jurisprudencia reiteradísima que el orden público no se activará cuando los cónyuges cumplan con tal requisito del divorcio alemán en el momento de pronunciación del repudio ${ }^{201}$.

\section{Relatividad del orden público internacional}

\subsection{Relatividad espacial}

55. El carácter nacional del orden público internacional impide al tribunal del foro invocar los principios esenciales de otros estados. Al mismo tiempo, la inaplicación de la ley extranjera sólo surtirá efectos en el foro ${ }^{202}$. Ambos estados delimitan el "radio de acción defensivo del orden público internaciona $^{203}$ a través de un criterio espacial.

Tal fundamentación tiene su origen en la doctrina alemana de Inlandsbeziehung, que examina el lugar en el que desplegará efectos el acto cuya constitución se pretende ${ }^{204}$. En España, esta técnica ha

${ }^{193} C f$. M. Mut Bosque et al., "Reflexiones sobre el repudio islámico y judío en el derecho civil y penal español: la institución del orden público internacional: Vol. II International Conference Family and Society”, 2015.

${ }^{194}$ Cf. ibid.

${ }^{195}$ Cf. S. Pérez Álvarez, "Las tradiciones ideológicas islámicas ante el repudio. Su eficacia civil en el derecho del estado español”, Ilu. Revista de Ciencia de las Religiones, núm. 13, 2008, pp. 183-223.

${ }^{196} C f$. BGH 26/08/2020, párr. 53 - 54.

${ }^{197} C f$. ATS 27/01/1998, FJ 2, citado por A.L. Calvo Caravaca \& J. Carrascosa González, "Crisis matrimoniales”, en A.L. Calvo Caravaca \& J. Carrascosa González (eds.), Derecho Internacional Privado: Vol. II, $18^{\mathrm{a}}$ ed., Comares, Granada, 2018, pp. 227-314.

${ }^{198}$ Cf. OLG Hamm 27/01/2010, p. 3.

${ }^{199} C f$. BGH 26/08/2020, párr. 56.

${ }^{200} \mathrm{Cf}$. V. GRIFo, "Bedingte Gastfreundschaft im Internationalen Scheidungsrecht", Neue Zeitschrift für das Familienrecht, núm. 5, 2021, pp. 202-207.

${ }^{201} C f$. BGH 26/08/2020, párr. 57; OLG Hamm 10/11/2010, p. 4; AG Kulmbach 28/10/2003, p.3.

${ }^{202} C f$. J.D. GonzÁlez Campos \& J.C. Fernández Rozas, "Orden público como correctivo funcional: Artículo 12, Apartado 3 del Código Civil”, en M. Albaladejo \& S. Díaz Alabart (eds.), Comentarios al Código Civil y Compilaciones forales, $5^{\text {a }}$ ed., Edersa, Madrid, 1995, pp. 894-926.

${ }^{203}$ J. CARrascosa GonzÁlez, "Orden público internacional y externalidades negativas", Boletín del Ministerio de Justicia, año 63, núm. 2065, 2008, pp. 5-32.

${ }^{204}$ Cf. I. BACH, "Islamisches Recht vor deutschen Gerichten = Law between Dialogue and Translation: Harmonizing National Law with International Law - The Case of Women`s Rights in Palestine”, Georg-August-Universität Göttingen, 2019. 
sido acogida como "flexibili ación del orden público internacional ${ }^{205}$ bajo la denominación orden público de proximidad. Parte desde la idea de que un vínculo con el foro aumenta la probabilidad de un daño para la estructura jurídica del fuero ${ }^{206}$.

56. Suele acudirse a los criterios de la residencia habitual de los cónyuges, la celebración de nupcias en el foro ${ }^{207} \mathrm{o}$ la nacionalidad, aunque algún autor español considera inadecuado ese último criterio para determinar un vínculo real con el foro ${ }^{208}$. En ambos países, el concepto de la conexión espacial ha levantado críticas al ser influenciable por las partes, verbi gratia, eligiendo su lugar de residencia o manteniendo la doble nacionalidad ${ }^{209}$. Ello provoca discrepancias en el acceso a los derechos fundamentales ${ }^{210}$. En el fondo del debate, subsiste una cuestión moral-filosófica ¿Son aplicables los derechos fundamentales a los extranjeros?

La frase segunda del art. 6 EGBGB exige un examen del ámbito de vigencia del derecho fundamental afectado, comprobándose su trascendencia en supuestos de tráfico externo ${ }^{211}$. Ello implica que existen derechos fundamentales cuya protección no corresponde al tribunal alemán en defecto de un vínculo con el foro.

En el sistema jurídico español, no existe un esquema privilegiado para los derechos fundamentales dentro del orden público internacional. Muy similar al enfoque alemán, los defensores de la función negativa del orden público internacional sostienen que el tribunal español debe comprobar si el derecho fundamental vulnerado tiene la consideración de absoluto ${ }^{212}$. Otros autores atribuyen al orden público internacional una función positiva que, por lo tanto, el tribunal del foro se encuentra obligado a proteger los derechos fundamentales de toda persona, sea de un nacional o extranjero, sin que sea preciso un examen de la conexión espacial ${ }^{213}$.

57. Ahora bien, la "europeización" del orden público internacional dio lugar a una "relajación de la relatividad espacial" 214 . Los derechos fundamentales internacionalmente recogidos no precisan de una conexión espacial porque su ámbito de aplicación es universa ${ }^{215}$. En términos similares, algún autor alemán desarrolló el "Indicador de Derecho Comparado"216.

${ }^{205}$ H. Aguilar Grieder, "Multiculturalidad, reconocimiento en España de repudios islámicos pronunciados en el extranjero y actuales tendencias del orden público en el D.I.Pr.", Cuestiones actuales de derecho comparado: actas de las reuniones académicas celebradas el 13 de julio de 2001 y el 10 de octubre de 2002 en la Facultad de Derecho de A Coruña, 2003, pp. 235-264.

${ }^{206}$ Cf. J. CARrascosa González, "Orden público internacional y externalidades negativas", Boletín del Ministerio de Justicia, año 63, núm. 2065, 2008, pp. 5-32.

${ }^{207}$ Cf. AG Garmisch-Partenkirchen 19/12/2006, p. 1.

${ }^{208} C f$. J. CARrascosa GonzÁlez, "Orden público internacional y externalidades negativas", Boletín del Ministerio de Justicia, año 63, núm. 2065, 2008, pp. 5-32.

${ }^{209} \mathrm{Cf}$. C. StaAth, „La excepción de orden público internacional como fundamento de denegación del reconocimiento del repudio islámico", Anuario Español de Derecho Internacional Privado, núm. 10, 2010, pp. 717-729; J. v. HeIn, "Internationales Privatrecht I - Allgemeiner Teil: Art. 6 EGBGB“, en F.J. SäcKER et al. (ed.), Münchener Kommentar zum BGB, $8 \mathrm{a}$ ed., vol. 12, C.H. Beck, Múnich, 2020.

${ }^{210}$ Cf. J. CARrascosa González, "Orden público internacional y externalidades negativas", Boletín del Ministerio de Justicia, año 63, núm. 2065, 2008, pp. 5-32.

${ }^{211} C f$. B. v. Hoffmann \& K. Thorn, “ §6. Grundbegriffe: Ordre Public“, en B. v. Hoffmann \& K. Thorn (eds.), Internationales Privatrecht, 9a ed., C.H. Beck, Múnich, 2007, pp. 136-154.

${ }^{212} C f$. J. CArrascosa GonzÁlez, "Orden público internacional y externalidades negativas", Boletín del Ministerio de Justicia, año 63, núm. 2065, 2008, pp. 5-32.

${ }^{213} C f$. H. A GUILAR GriedER, "Multiculturalidad, reconocimiento en España de repudios islámicos pronunciados en el extranjero y actuales tendencias del orden público en el D.I.Pr.", Cuestiones actuales de derecho comparado: actas de las reuniones académicas celebradas el 13 de julio de 2001 y el 10 de octubre de 2002 en la Facultad de Derecho de A Coruña, 2003, pp. 235-264.

${ }^{214} \mathrm{Ibid}$.

${ }^{215} C f$. P. Scholz, "Grundfälle zum IPR: Ordre public - Vorbehalt und islamisch geprägtes Recht - Teil 1 (Allgemeiner Teil)“, Zeitschrift für das Juristische Studium, núm. 2, 2010, pp. 185-197.

${ }^{216}$ E. JAYME, "Methoden der Konkretisierung des ordre public im Internationalen Privatrecht", JuRistische StUdiENGESELLSCHAFt KaRLSRUHe (ed.), núm. 183, C.F. Müller Juristischer Verlag, Heidelberg, 1985. 
Ello es válido para el repudio justificado con base al art. 10 Reglamento (UE) 1259/2010 por referencia, el cual se basa en el principio de igualdad del art. 21 Carta de los Derechos Fundamentales de la UE ${ }^{217}$. No obstante, algún autor español matiza que el tribunal no debe invocar principios recogidos por textos internacionales si el país de origen del litigante no forma parte de dicho tratado ${ }^{218}$.

Ello es problemático en relación con el repudio, porque los estados de tradición islámica mantienen una visión particular acerca del principio de igualdad, lo que se refleja en la codificación del principio en textos regionales ${ }^{219}$. Su codificación fragmentada impide asumir la vigencia universal del principio de igualdad. Por lo contrario, subsiste la necesidad de alegar una conexión espacial para superar esa "carga política" 220 frente al estado de origen. Aún más altas serán las exigencias a la conexión espacial cuando se pretenda invocar el orden público internacional con motivo del monopolio estatal de pronunciación sobre el divorcio, valor que - en contraste con el principio de igualdad - no cuenta con un respaldo sólido a nivel global.

\subsection{Relatividad temporal}

58. Ya en 1966, el TS estableció que el orden público internacional refleja los principios esenciales de "una época determinada" 221 . Considerando que los valores integrados en el orden público internacional son cambiantes en función de la realidad social, se aplica de modo unánime el principio de la actualidad, pues el contenido del orden público internacional se aprecia en el momento de planteamiento del litigio ${ }^{222}$. Lo mismo ocurre en Alemania, dónde se examina si el vínculo con el foro ha existido en ese mismo momento ${ }^{223}$.

59. Respecto al divorcio, los elementos del orden público internacional español y alemán experimentaron un giro radical. En España, el principio de indisolubilidad del matrimonio vencía a las normas extranjeras. En los años 60, los tribunales procedieron a conceder efectos atenuantes al divorcio, aun eludiendo su efecto nuclear mediante orden público internacional ${ }^{224}$. Con la entrada en vigor de la Constitución española, la indisolubilidad del divorcio desapareció como elemento del orden público internacional ${ }^{225}$. De todos modos, en la actualidad, se activa el orden público internacional frente a leyes extranjeras que no permiten el divorcio ${ }^{226}$. En Alemania, el Kranzgeld, una pretensión compensatoria de la mujer divorciada por la pérdida de la virginidad, formaba parte del orden público internacional hasta $1958^{227}$. Más tarde, ese principio fue inaplicado en supuestos de tráfico externo hasta que fue derogado completamente en 1998 por su contrariedad al principio de igualdad del art. $3.2 \mathrm{GG}^{228}$. En la actualidad, todo efecto discriminatorio sobre uno de los cónyuges se rechaza mediante la excepción del orden pú-

\footnotetext{
${ }^{217}$ Cf. M.P. Weller et al., 2016, p. 127.

${ }^{218}$ Cf. J. Carrascosa GonzÁlez, "Orden público internacional y externalidades negativas", Boletín del Ministerio de Justicia, año 63, núm. 2065, 2008, pp. 5-32.

${ }^{219} \mathrm{Cf}$. C. StaAth, „La excepción de orden público internacional como fundamento de denegación del reconocimiento del repudio islámico", Anuario Español de Derecho Internacional Privado, núm. 10, 2010, pp. 717-729.

${ }^{220}$ A.L. Calvo Caravaca \& J. Carrascosa González, "Crisis matrimoniales", en A.L. Calvo Caravaca \& J. Carrascosa GonZÁlEZ (eds.), Derecho Internacional Privado: Vol. II, $18^{\mathrm{a}}$ ed., Comares, Granada, 2018, pp. 227-314.

${ }^{221}$ STS 05/04/1966.

${ }^{222} C f$. .C. Fernández Rozas \& S. Sánchez Lorenzo, "Capítulo III. Derecho aplicable”, en J.C. Fernández Rozas \& S. SánCHEz Lorenzo (eds.), Derecho Internacional Privado, $9^{\text {a }}$ ed., Civitas-Thomson Reuters, Navarra, 2016, pp. 83-157.

${ }^{223}$ Cf. I. BACH, "Islamisches Recht vor deutschen Gerichten = Law between Dialogue and Translation: Harmonizing National Law with International Law - The Case of Women`s Rights in Palestine”, Georg-August-Universität Göttingen, 2019.

${ }^{224}$ Cf. J.D. González CAmpos \& J.C. Fernández Rozas, "Orden público como correctivo funcional: Artículo 12, Apartado 3 del Código Civil”, en M. Albaladejo \& S. Díaz Alabart (eds.), Comentarios al Código Civil y Compilaciones forales, $5^{\text {a }}$ ed., Edersa, Madrid, 1995, pp. 894-926.

${ }^{225}$ Cf. ibid.

${ }^{226}$ Vid. Art. 10 Alt. 1 RRIII.

${ }^{227} C f$. B. v. Hoffmann \& K. Thorn “ $§ 6$. Grundbegriffe: Ordre Public“, en B. v. Hoffmann \& K. Thorn (eds.), Internationales Privatrecht, 9a ed., C.H. Beck, Múnich, 2007, pp. 136-154.

${ }^{228} C$ Cf. id.
} 
blico internacional. De los dos ejemplos históricos se desprende que el orden público internacional es convertible y faculta al juez plasmar el cambio de valores sociales. ${ }^{229}$

\section{Efectos}

60. Una vez inaplicada la ley extranjera, la configuración negativa del orden público internacional provoca un "vacío legal" ${ }^{230}$. Lo más inmediato es recurrir a los preceptos relativos al divorcio de la lex fori. Esa es la solución prevista por el art. 10 Reglamento (UE) 1259/2010 aplicado por referencia en España, quitando al tribunal la carga justificativa.

El art. 10 está diseñado en el espíritu del "sistema latino", teoría predominante en los sistemas jurídicos europeos ${ }^{231}$ que asume que, cuando el vínculo espacial con el foro sea considerado suficiente para invocar el orden público internacional, ello legitima aplicar la lex fori como ley más cercana al asunto. La solución del art. 10 Reglamento (UE) 1259/2010 armoniza con la jurisprudencia española "casi unánime" 232 en favor de su aplicación automática. Tampoco es una solución inhabitual en la jurisprudencia alemana ${ }^{233}$. Desde el punto de vista del foro, aminora el riesgo de colisiones con la estructura jurídica básica del foro ${ }^{234}$. Por el contrario, incrementa el riesgo de que la sentencia no sea reconocida en el estado de origen ${ }^{235}$. Además, provoca problemas de competencia si la ley extranjera regula cuestiones accesorias del divorcio no previstas por la lex fori.

Para ponderar esos riesgos, la doctrina española rechaza la aplicación automática de la lex fori y defiende una solución individual ${ }^{236}$. Se ha propuesto acudir a un ordenamiento jurídico de la misma familia jurídica ${ }^{237}$, aplicar la segunda ley elegida por los cónyuges por medio del Reglamento (UE) 1259/2010 (si lo hubiese) ${ }^{238}$ o acudir al punto de conexión subsidiario (si lo hubiese). ${ }^{239}$ En ese sentido, se observa un esfuerzo de la jurisprudencia alemana de acudir a la lex fori subsidiariamente ${ }^{240}$ y "tan cuidadoso como sea posible"241.

61. Otra solución frecuente de la jurisprudencia alemana se basa en el orden público internacional parcial, concepto que se deduce del tenor literal de los art. 12.3 CC y art. 6 EGBGB. ${ }^{242}$ Aunque

${ }^{229}$ Cf. E. JAYME, "Methoden der Konkretisierung des ordre public im Internationalen Privatrecht", JuRISTISCHE STUDIENGESellschaft Karlsruhe (ed.), núm. 183, C.F. Müller Juristischer Verlag, Heidelberg, 1985.

${ }^{230}$ J. CARrascosa GonzÁlez, "Orden público internacional y externalidades negativas", Boletín del Ministerio de Justicia, año 63, núm. 2065, 2008, pp. 5-32.

${ }^{231} C f$. A.L. Calvo Caravaca \& J. Carrascosa González, "Crisis matrimoniales”, en A.L. Calvo Caravaca \& J. CarrascoSA GonzÁlez (eds.), Derecho Internacional Privado: Vol. II, $18^{\mathrm{a}}$ ed., Comares, Granada, 2018, pp. 227-314.

${ }^{232}$ A. YBarra Bores, "Los problemas de aplicación del sistema de derecho internacional privado", en A. RodríGUEz BENOT et al. (ed.), Manual de derecho internacional privado, $6^{\mathrm{a}}$ ed., Tecnos, Madrid, 2019, pp. 149-162.

${ }^{233}$ Cf. OLG Hamm 11.10.2010, FJ 2; OLG Kulmbach 28/10/2003, p. 3; OLG Zweibrücken 16/11/2001, p.2.

${ }^{234}$ Cf. J. Carrascosa González, "Orden público internacional y externalidades negativas", Boletín del Ministerio de Justicia, año 63, núm. 2065, 2008, pp. 5-32.

${ }^{235} C f$. Ma . D. Ortiz Vidal, "El repudio en el Código de Familia de Marruecos y la aplicación del derecho marroquí en la UE”, Cuadernos de Derecho Transnacional, vol. 6, núm. 2, 2014, pp. 201-244.

${ }^{236}$ Cf. A. YBarra Bores, "Los problemas de aplicación del sistema de derecho internacional privado", en A. RodríGUEZ Benot et al. (ed.), Manual de derecho internacional privado, $6^{a}$ ed., Tecnos, Madrid, 2019, pp. 149-162.

${ }^{237}$ Cf. ibid.

${ }^{238}$ Cf. A.L. Calvo Caravaca \& J. Carrascosa González, "Crisis matrimoniales”, en A.L. Calvo Caravaca \& J. CarrascoSA González (eds.), Derecho Internacional Privado: Vol. II, $18^{\mathrm{a}}$ ed., Comares, Granada, 2018, pp. 227-314.

${ }^{239}$ Cf. A. YBarra Bores, "Los problemas de aplicación del sistema de derecho internacional privado", en A. RodríGUEZ Benot et al. (ed.), Manual de derecho internacional privado, 6 a ed., Tecnos, Madrid, 2019, pp. 149-162.; J. CARrascosa GonZÁLEZ, "Orden público internacional y externalidades negativas", Boletín del Ministerio de Justicia, año 63, núm. 2065, 2008, pp. 5-32.

${ }^{240} C f$. B. v. Hoffmann \& K. Thorn, “ $§ 6$. Grundbegriffe: Ordre Public“, en B. v. Hoffmann \& K. Thorn (eds.), Internationales Privatrecht, 9a ed., C.H. Beck, Múnich, 2007, pp. 136-154.

${ }^{241}$ E. JAYME, "Methoden der Konkretisierung des ordre public im Internationalen Privatrecht", JuRISTISCHE StUdiengeSELLschaft Karlsruhe (ed.), núm. 183, C.F. Müller Juristischer Verlag, Heidelberg, 1985.

${ }^{242}$ Vid. párr. 16 y 21. 
algunas de las disposiciones de la ley extranjera sean incompatibles con el orden público internacional, se intenta dar efecto a las restantes normas en la medida de lo posible. ${ }^{243}$ Ello permite someter los efectos periféricos del divorcio a la ley extranjera ${ }^{244}$. A modo de ejemplo, la Ley afgana prevé un intento de reconciliación para la validez del divorcio tras repudio, por lo que un tribunal alemán ordenó la intervención de un mediador experto antes de disolver el matrimonio conforme a la lex fori ${ }^{245}$. Aun así, se intenta elegir una modalidad disolutiva que existe en ambos sistemas para evitar situaciones claudicantes. ${ }^{246}$ Desafortunadamente, el tenor del art. 10 Reglamento (UE) 1259/2010 sugiere la derogación completa de la ley extranjera ${ }^{247}$, de donde se deduce que la aplicación del art. 10 por referencia no permite usar el orden público parcial en España.

\section{El orden público internacional en sede de reconocimiento. Análisis comparativo del enfoque español y alemán}

\section{Requisitos para el reconocimiento de divorcios privados}

62. Podrán ser objeto de control del orden público internacional, los repudios con o sin intervención judicial. No obstante, el grado de intensidad del control varía entre el orden público internacional de ley aplicable y el orden público internacional de reconocimiento. El último sólo se comprueba si la disolución del matrimonio tras repudio puede ser homologada a una sentencia extranjera.

\subsection{Acto de una autoridad estatal}

63. En primer lugar, la resolución ha de provenir de un órgano jurisdiccional. En el repudio suelen intervenir órganos estatales no judiciales -notarios, u órganos no estatales, públicos o religiosos-. El art. 43 c) LCJIMC dispone de una definición amplia, cubriendo todo órgano con competencias análogas a la autoridad judicial española, esto es, si tiene imperium o "capacidad de control sobre los requisitos previstos para que pueda ser decretado" 248 . El BGH acude al mismo criterio y homologa la autoridad si tiene atribuida la facultad de conocer de litigios de derecho privado ${ }^{249}$. En segundo lugar, el acto tiene que resultar de la intervención de dicho órgano. No todo repudio es un divorcio privado. Así, la doctrina alemana y española clasifican el repudio en tres grupos:

Acto judicial: No es un divorcio privado. La autoridad interviene en el acto a efectos constitutivos, es decir, el matrimonio no queda disuelto sin su intervención. Su prototipo es el repudio marroquí que se somete a la autorización previa por el juez cuyas "funciones son, obviamente, jurisdiccionales" 250 , por lo que el acto se homologa a una sentencia extranjera susceptible de reconocimiento procesal. En defecto de aplicabilidad del Reglamento (CE) 2201/2003 son aplicables las cláusulas de orden público internacional de reconocimiento del art. 46.1 a) LCJIMC y del art. $328.4 \mathrm{ZPO}^{251}$.

${ }^{243} C f$. A. Ybarra Bores, "Los problemas de aplicación del sistema de derecho internacional privado", en A. RodríGUEZ Benot et al. (ed.), Manual de derecho internacional privado, $6^{\text {a }}$ ed., Tecnos, Madrid, 2019, pp. 149-162.

${ }^{244}$ Cf. AG Garmisch-Partenkirchen 19/12/2006, p. 6, OLG Hamm 27/01/2010, p. 3.

${ }^{245}$ Cf. OLG Hamburg 21/03/2000.

${ }^{246} C f$. OLG Düsseldorf 03/11/1997, FJ 1.

${ }^{247}$ Vid. Conclusiones del abogado general Saugmansgaard Øe, Asunto C-372/16 (Soha Sahyouni contra Raja Mamisch), 2017, párr. 82.

${ }^{248}$ N. Marchal Escalona, "La eficacia en España de los divorcios extrajudiciales otorgados en el extranjero", Cuadernos de Derecho Transnacional, vol. 13, núm. 1, 2021, pp. 460-492.

${ }^{249}$ Cf. BGH 26/08/2020, párr. 17.

${ }^{250}$ STS 25/01/2006, FJ 7.

${ }^{251}$ Cf. S. Rutten, "Recognition of Divorce by Repudiation (talaq) in France, Germany and the Netherlands", Maastricht Journal of European and Comparative Law, vol. 11, núm. 3, 2004, pp. 263-285. 
Acto notarial: En esos divorcios privados interviene una autoridad para dar fe al acto previamente constituido. La doctrina española y alemana deniegan su carácter de una "decisión" porque la intervención de la autoridad carece de una noción constitutiva, pues no decide sobre la validez de la disolución matrimonial ${ }^{252}$. Corresponde al legislador nacional decidir si el reconocimiento se somete a requisitos procesales o sustantivos ${ }^{253}$. El $\mathrm{BGH}^{254}$ sostiene que en dichos procesos no se examina un acto oficial, sino un negocio jurídico privado al cual será aplicable la regulación sustantiva del art. 17 EGBGB. Con arreglo al § 107.1 FamFG, la administración judicial federal realiza una revisión a fondo y emite una decisión sustantiva propia sobre el divorcio ${ }^{255}$. En España, dicho acto se asimila a una cuestión de ley aplicable al divorcio. Así pues, en ambos países el reconocimiento de dicha clase de repudio es sustantivo, cumpliendo con una función sustituidora de la intervención oficial faltante. Siendo aplicables los artículos 10 Reglamento (UE) 1259/2010 por referencia y el art. 6 EGBGB, es válido para esos repudios lo dicho respecto al orden público internacional de ley aplicable ${ }^{256}$.

Acto privado: Son los divorcios privados "puros" sin intervención alguna. Una vez pronunciado el repudio, despliega efectos disolutivos inmediatamente. Se considera inexistente en España porque los actos privados no son inscribibles en el Registro Civil257. En Alemania, se deniega la competencia del tribunal de reconocer un acto si la lex causae no prevé la intervención de autoridad estatal alguna en ello $^{258}$. No son reconocibles, ni de modo procesal ni de modo sustantivo.

\subsection{Firmeza}

64. "Una decisión extranjera es firme desde el momento en el que no es susceptible de ulterior recurso ni modificación ${ }^{259}$. Es jurisprudencia reiterada en España que sólo serán calificados firmes los repudios irrevocables. El paradigmático ATS de 8 de junio de 1999 estableció que será reconocible el acto proveniente de una autoridad extranjera que garantice "de manera clara e inequívoca que se trata de una disolución definitiva e irrevocable del matrimonio ${ }^{260}$. Dicho examen es sumamente relevante en España donde se admite la separación, situación que permite reanudar el vínculo matrimonial por lo que "guarda cierta semejanza" con la $i d d a$, fase que permite la revocación del repudio ${ }^{261}$. También es relevante, para garantizar que la subsistencia del matrimonio no sea condicionada por la voluntad de uno de los cónyuges, en cuyo caso el orden público internacional no será examinado ${ }^{262}$. Aunque la separación no existe en Alemania, el carácter revocable es relevante para calificar la esolución extranjera cómo firm ${ }^{263}$.

${ }^{252} C f$. A.L. Calvo Caravaca \& J. Carrascosa González, "Crisis matrimoniales”, en A.L. Calvo Caravaca \& J. CarrascoSA González (eds.), Derecho Internacional Privado: Vol. II, $18^{\mathrm{a}}$ ed., Comares, Granada, 2018, pp. 227-314.

${ }^{253} C f$. M. PIKa \& M.P. Weller, "Privatscheidungen zwischen Europäischem Kollisions- und Zivilprozessrecht", Praxis des Internationalen Privat- und Verfahrensrechts (IPRax), núm. 1, 2017, pp. 65-72.

${ }^{254} C f$. BGH 28/05/2008, citado por ibid.

${ }^{255}$ Cf. ibid.

256 Vid. párr. 43-61.

${ }^{257} C f$. A.L. Calvo Caravaca \& J. Carrascosa González, "Crisis matrimoniales”, en A.L. Calvo Caravaca \& J. Carrascosa GonzÁlez (eds.), Derecho Internacional Privado: Vol. II, 18ª ed., Comares, Granada, 2018, pp. 227-314.

${ }^{258}$ Cf. M. PIKA \& M.P. Weller, "Privatscheidungen zwischen Europäischem Kollisions- und Zivilprozessrecht", Praxis des Internationalen Privat- und Verfahrensrechts (IPRax), núm. 1, 2017, pp. 65-72.

${ }^{259} \mathrm{M}^{\mathrm{a}}$. D. OrTiz Vidal, "El repudio en el Código de Familia de Marruecos y la aplicación del derecho marroquí en la UE", Cuadernos de Derecho Transnacional, vol. 6, núm. 2, 2014, pp. 201-244.

${ }^{260}$ S. PÉrez Álvarez, "Las tradiciones ideológicas islámicas ante el repudio. Su eficacia civil en el derecho del estado español”, Ilu. Revista de Ciencia de las Religiones, núm. 13, 2008, pp. 183-223. Cf. BGH 26/08/2020, párr. 53 - 54.

${ }^{261}$ A. QuiÑonEs EsCÁMEZ, "La disolución del matrimonio: especial referencia al repudio islámico", en A. RoDríGUEZ BENOT (ed.), La multiculturalidad: Especial referencia al Islam, Consejo General del Poder Judicial, Madrid, 2002, pp. 259-342.

${ }^{262}$ Cf. ATS 21/04/1998; FJ 3, ATS 18/02/2003, FJ 2.

${ }^{263}$ Cf. P. Winkler v. Mohrenfels, "Internationales Privatrecht I - Internationales Familienrecht: Art. 10 Rom III-VO“, en F.J. SÄCKER et al. (ed.), Münchener Kommentar zum BGB, 8ª ed., vol. 12, C.H. Beck, Múnich, 2020. 


\subsection{Vulneración de garantías procesales}

65. El orden público internacional en sede de reconocimiento defiende principios materiales o procesales del foro. El control del orden público internacional material sigue los criterios del orden público internacional de ley aplicable. ${ }^{264}$ Por lo contrario, el orden público procesal sólo se examina en el marco del reconocimiento. El repudio suele chocar con el derecho a la tutela judicial efectiva, art. 24.1 CE y el derecho a ser oído, art. 103.1 GG. No toda divergencia entre las garantías procesales del foro y las disposiciones del estado de origen del acto extranjero activa el orden público internacional. En Alemania, la garantía vulnerada debe tener carácter imprescindible para el proceso en un estado de derecho, ${ }^{265}$ exempli gratia cuando el divorcio se obtenga de forma dolosa o mediante documentos falsificado ${ }^{266}$. En España, debe garantizarse un "derecho a ser citado y/o emplazado regularmente y con tiempo suficiente para defenderse ${ }^{267}$.

66. El repudio clásico está configurado como declaración de voluntad unilateral que no precisa de su recepción por la mujer ${ }^{268}$. Así pues, guarda un estrecho vínculo con el carácter discriminatorio, concediendo al varón un margen de apreciación sobre la efectividad de la notificación. La ausencia de forma escrita provoca la indefensión de la mujer ${ }^{269}$. Según jurisprudencia alemana, esta no ha sido válidamente notificada si es invitada a defenderse ante el tribunal sin conocer la intención del varón de repudiarla ${ }^{270}$. El auto reciente de algún tribunal español sugiere que no basta con la mera notificación del repudio. Debe asegurase la participación de la mujer en el proceso de disolución del divorcio ${ }^{271}$. En su defecto, el orden público internacional alemán se activa también ${ }^{272}$. La diversidad de regulaciones procesales del repudio en los países musulmanes impide el desarrollo de un catálogo de criterios para el grado suficiente de participación de la mujer. Los tribunales españoles están particularmente familiarizados con el sistema marroquí273 cuyo régimen procesal es ejemplar para la integración de la mujer repudiada. El repudio no se autoriza antes del agotamiento de toda vía de reconciliación ${ }^{274}$ lo que implica la participación de la mujer y evita la activación del orden público internacional. Aun así, el orden público internacional ha sido invocado frente a cuestiones accesorias, a modo de ejemplo cuando la pensión alimenticia se fija por el abogado del varón en vez de un mutuo acuerdo entre los cónyuges ${ }^{275}$. En Alemania, el examen de la intervención de la mujer repudiada en el proceso no se orienta en un prototipo tal cómo el marroquí en España, sino que se acude a una fórmula abstracta desarrollada por el BVerfG. El derecho a ser oído se entiende vulnerado cuando las reglas procesales transforman a la mujer en un mero objeto pasivo en vez de sujeto titular de garantías procesales ${ }^{276}$. La transposición de la así llamada Objektformel al control de orden público internacional demuestra que la frase segunda del art. 6 EGBGB constituye una puerta de entrada no sólo para los derechos fundamentales, sino también para la doctrina constitucional.

${ }^{264}$ Vid. párr. 43-61.

${ }^{265} C f$. D. BAetKe, 2020, "Band 6: Internationales Privatrecht und UN-Kaufrecht: Art. 6 EGBGB“, en M. WÜRdingER (ed.), Juris PraxisKommentar BGB, 9.a ed., Juris GmbH, Saarbrücken, 2020.

${ }^{266} C f$. BayObLG 28/07/1999, FJ 2.

${ }^{267}$ H. Aguilar Grieder, "Multiculturalidad, reconocimiento en España de repudios islámicos pronunciados en el extranjero y actuales tendencias del orden público en el D.I.Pr.", Cuestiones actuales de derecho comparado: actas de las reuniones académicas celebradas el 13 de julio de 2001 y el 10 de octubre de 2002 en la Facultad de Derecho de A Coruña, 2003, pp. 235-264.

${ }^{268} C f$. OLG Stuttgart 03/05/2019, párr. 12.

${ }^{269} \mathrm{Cf}$. M. Mut Bosque et al., "Reflexiones sobre el repudio islámico y judío en el derecho civil y penal español: la institución del orden público internacional: Vol. II International Conference Family and Society", 2015.

${ }^{270}$ Cf. S. RutTen, "Recognition of Divorce by Repudiation (talaq) in France, Germany and the Netherlands", Maastricht Journal of European and Comparative Law, vol. 11, núm. 3, 2004, pp. 263-285.

${ }^{271} C f$. AAP Málaga 29/01/2015, FJ 5.

${ }^{272} C f$. OLG Stuttgart 03/05/2019, párr. 10.

${ }^{273} C f$. A. QuiÑones EsCÁMEZ, "La disolución del matrimonio: especial referencia al repudio islámico", en A. RodRíGUEZ BENOT (ed.), La multiculturalidad: Especial referencia al Islam, Consejo General del Poder Judicial, Madrid, 2002, pp. $259-342$.

${ }^{274}$ Cf. STS 25/01/2006, FJ 5.

${ }^{275}$ Cf. AAP Guipúzcoa 09/03/2018, FJ 2.

${ }^{276} C f$. OLG Stuttgart 03/05/2019, párr. 13. 


\section{Intensidad de la incompatibilidad}

67. En ambos sistemas jurídicos, "el grado de tolerancia va a ser mucho mayor" 277 frente a una situación jurídica creada en el extranjero porque la falta de una conexión espacial aminora el riesgo de un perjuicio para los valores esenciales del foro. Por el contrario, si los cónyuges residen en el foro, pero el varón insta un repudio en el extranjero, su reconocimiento elude un proceso de divorcio ante un tribunal del foro. El así llamado "repudio migratorio" 278 ocupa a la doctrina de ambos países. Los tribunales españoles lo enfrentan verificando la competencia del tribunal de origen mientras que los alemanes incluso lo califican cómo fraude de le ${ }^{279}$.

La menor intensidad del orden público internacional por motivo de la distancia geográfica se denomina orden público internacional atenuado en España y effet atténué en Alemania. Las resoluciones extranjeras se someten a un pronunciamiento declarativo en España, siendo prohibido toda revisión del fondo $^{280}$ que exceda del marco necesario para el control del orden público internacional ${ }^{281}$.

68. Asimismo, el procedimiento alemán "privilegiado" 282 de los $\S \S 108,109$ FamFG prevé una examinación escasa y limitada, regida por los principios de prohibición de revisión al fondo y el principio de confianz ${ }^{283}$. No cabe la activación automática del orden público internacional frente al acto de divorcio tras repudio ${ }^{284}$. En Alemania, sólo opera cuando el repudio evidentemente revista el carácter de un provecho arbitrario de las facultades exclusivas del varón, ${ }^{285} \mathrm{o}$ cuando la mujer figurase como mero objeto del proceso de divorcio ${ }^{286}$. En España, y aunque el art. 46.1 a) LCJIMC no lo recoja, el repudio debe provocar una incompatibilidad manifiesta ${ }^{287}$, por lo que sólo opera frente al repudio clásico unilateral con una evidente nota discriminatoria ${ }^{288}$.

\section{3. Ámbito de control}

69. En los supuestos de orden público internacional de ley aplicable, el consentimiento de la mujer se interpreta de modo restrictivo. Resulta difícil delimitar entre la voluntad respecto al divorcio y/o la forma externa del repudio ${ }^{289}$. Por el contrario, en el ámbito de reconocimiento, esa dificultad no existe porque la solicitud instada por la mujer ya implica su intención de reconocer los efectos del divorcio mediante repudio.

${ }^{277}$ H. Aguilar Grieder, "Multiculturalidad, reconocimiento en España de repudios islámicos pronunciados en el extranjero y actuales tendencias del orden público en el D.I.Pr.", Cuestiones actuales de derecho comparado: actas de las reuniones académicas celebradas el 13 de julio de 2001 y el 10 de octubre de 2002 en la Facultad de Derecho de A Coruña, 2003, pp. 235-264.

${ }^{278}$ A. QuiÑones EscÁmez, "La disolución del matrimonio: especial referencia al repudio islámico", en A. RodRíGUEZ BENOT (ed.), La multiculturalidad: Especial referencia al Islam, Consejo General del Poder Judicial, Madrid, 2002, pp. $259-342$.

${ }^{279}$ Vid. e.g. OLG Stuttgart 03/05/2019, párr. 17.

${ }^{280} \mathrm{Vid}$. art. 48 LCJIMC.

${ }^{281}$ Cf. AAP Málaga 29/01/2015, FJ 2.

${ }^{282}$ M. PIKA \& M.P. Weller, "Privatscheidungen zwischen Europäischem Kollisions- und Zivilprozessrecht", Praxis des Internationalen Privat- und Verfahrensrechts (IPRax), núm. 1, 2017, pp. 65-72.

${ }^{283} C f$. BGH 26/08/2020, párr. 23.

${ }^{284} C f$. D. BAETKe, 2020, "Band 6: Internationales Privatrecht und UN-Kaufrecht: Art. 6 EGBGB“, en M. WÜRDINGER (ed.), Juris PraxisKommentar BGB, 9.a ed., Juris GmbH, Saarbrücken, 2020.

${ }^{285}$ Cf. S. RutTen, "Recognition of Divorce by Repudiation (talaq) in France, Germany and the Netherlands", Maastricht Journal of European and Comparative Law, vol. 11, núm. 3, 2004, pp. 263-285.

${ }^{286} C f$. OLG Stuttgart 03/05/2019, párr. 13.

${ }^{287} C f$. N. Magallón Elósegui, "Reconocimiento y ejecución parcial de resoluciones judiciales extranjeras y orden público en la Ley de Cooperación Jurídica Internacional en materia civil. Comentario al auto de la Audiencia Provincial de Gipuzkoa (Sección 2a) núm. 120/2018, de 9 de marzo", Cuadernos de Derecho Transnacional, vol. 11, núm. 1, 2019, pp. 834-840.

${ }^{288} C f$. A.L. Calvo Caravaca \& J. Carrascosa González, "Crisis matrimoniales", en A.L. Calvo Caravaca \& J. CarrascoSA GonzÁlez (eds.), Derecho Internacional Privado: Vol. II, $18^{\text {a }}$ ed., Comares, Granada, 2018, pp. 227-314.

${ }^{289}$ Vid. párr. 54. 
70. Frente a un proceso de divorcio en el foro, el reconocimiento del repudio supone un modo "más usual, fácil, rápido y económico" ${ }^{290}$. Así pues, cuando la mujer repudiada insta el reconocimiento, suele ser admitido por los tribunales españoles ${ }^{291}$ y alemanes ${ }^{292}$, salvo que coincidiese con otra solicitud de disolución del divorcio ante un tribunal del foro. ${ }^{293}$ Es más, la jurisprudencia española sostiene que una aplicación rigurosa del orden público internacional pueda acabar en una doble vulneración de sus garantías procesales ${ }^{294}$. La denegación del reconocimiento obligaría a la mujer a iniciar un proceso de divorcio en España, que acabaría en el mismo resultado, pero con un adicional perjuicio económico y moral ${ }^{295}$. Además, privaría a la mujer de su derecho a contraer segundas nupcias al subsistir un impedimento de ligamen conforme a las normas del Código Civil ${ }^{296}$.

Todo ello convierte la admisión del reconocimiento instado por la mujer en un "imperativo impuesto a los poderes públicos”297. En términos menos explícitos, el BGH reconoce que su denegación priva a la mujer de la autonomía de decidir sobre la forma exterior de su divorcio ${ }^{298}$.

71. Esa doctrina del control de resultado sólo es vigente en supuestos de reconocimiento procesal del repudio, siendo aplicables las clásicas cláusulas nacionales de orden público internacional de reconocimiento que producen resultados casi idénticos en ambos países. Así, ante un reconocimiento sustantivo se produce una vez más la colisión entre los requisitos clásicos del art. 6 EGBGB y el tenor literal abstracto del art. 10 (UE) Reglamento 1259/2010 aplicable por referencia en España.

Mientras que la solución alemana no diverge de los supuestos de reconocimiento procesal, la aplicabilidad del control de resultado al reconocimiento sustantivo es discutida ${ }^{299}:$ ¿Debe admitirse la solicitud de reconocimiento instada por la mujer o prevalece la defensa imperativa de sus garantías procesales?

Si se optase por una interpretación abstracta del art. 10, se aplicaría un doble rasero a las mujeres repudiadas. Aquellas solicitudes de reconocimiento de un repudio clasificado como acto judicial serían admitidas para evitar la doble discriminación procesal, mientras que las solicitudes de reconocimiento de un repudio clasificado como acto notarial serían denegadas, poniendo "el formalismo del principio igualitario por encima del resultado material que se produce en el caso concreto" 300 .

Ese trato desigual discrimina a la última, que es privada de las ventajas del reconocimiento en vez de otro proceso de divorcio en el foro, aunque no puede hacer nada al respecto de la forma de su repudiación. Por ello, urge que el legislador español se asegure de la aplicabilidad del control de resultado en supuestos de reconocimiento procesal y material.

${ }^{290}$ A. QuiÑones EscÁMEZ, "La disolución del matrimonio: especial referencia al repudio islámico”, en A. RodRíGUEZ BENOT (ed.), La multiculturalidad: Especial referencia al Islam, Consejo General del Poder Judicial, Madrid, 2002, pp. 259-342.

${ }^{291}$ Vid. ATS 21/04/1998; ATS 18/05/2004.

${ }^{292} C f$. BGH 06/10/2004, párr. 4 d).

${ }^{293} C f$. OLG Stuttgart 03/05/2019, párr. 15.

${ }^{294}$ H. Aguilar Grieder, "Multiculturalidad, reconocimiento en España de repudios islámicos pronunciados en el extranjero y actuales tendencias del orden público en el D.I.Pr.", Cuestiones actuales de derecho comparado: actas de las reuniones académicas celebradas el 13 de julio de 2001 y el 10 de octubre de 2002 en la Facultad de Derecho de A Coruña, 2003, pp. 235-264.

${ }^{295} C f$. ATS 21/04/1998, FJ 3.

${ }^{296} C f$. S. Pérez Álvarez, "Las tradiciones ideológicas islámicas ante el repudio. Su eficacia civil en el derecho del estado español”, Ilu. Revista de Ciencia de las Religiones, núm. 13, 2008, pp. 183-223.

Cf. BGH 26/08/2020, párr. $53-54$.

${ }^{297} \mathrm{Id}$.

${ }^{298}$ Cf. BGH 26/08/2020, párr. 54.

299 Vid. párr. 51-52.

${ }^{300}$ H. AgUilar Grieder, "Multiculturalidad, reconocimiento en España de repudios islámicos pronunciados en el extranjero y actuales tendencias del orden público en el D.I.Pr.", Cuestiones actuales de derecho comparado: actas de las reuniones académicas celebradas el 13 de julio de 2001 y el 10 de octubre de 2002 en la Facultad de Derecho de A Coruña, 2003, pp. 235-264. 


\section{Efectos atenuantes}

72. Es común que la decisión extranjera se pronuncie sobre cuestiones accesorias a la mera disolución del matrimonio, ${ }^{301}$ p.ej. alimentos, tutela, pensión, etc.

La subdivisión del orden público internacional de reconocimiento en efectos nucleares y accesorios $^{302}$ permite admitir efectos que no resultan incompatibles con el orden público internacional ${ }^{303}$ y que se admiten para "evitar injusticias mayores" 304 .

73. El concepto de los efectos atenuantes tiene su origen en España en una época en la cual el principio de indisolubilidad del matrimonio provocaba la frecuente intervención del orden público internacional. Fue desarrollado por la Dirección General de Registros y Notariado, hoy Dirección General de Seguridad Jurídica y Fe Pública, que enfrentaba los detalles técnicos y menos solemnes alrededor del divorcio extranjero ${ }^{305}$. En su excelsa Resolución del 18 de septiembre de 1971, admitió la inscripción de un matrimonio civil entre una española y un saharaui, pese a que el varón había repudiado a sus dos esposas anteriores $^{306}$.

El reconocimiento del efecto principal no fue denegado por motivo de la unilateralidad del repudio, sino por razón del principio de indisolubilidad del matrimonio ${ }^{307}$. Ese último provocó la necesidad de crear un compromiso "entre continuidad transfronteriza e integridad de la estructura jurídica de la sociedad española" ${ }^{308}$.

74. En la actualidad, se refleja en los artículos 49 y 50.3 LCJIMC que permiten la solicitud y admisión parcial del reconocimiento, instrumento útil para evitar la activación del orden público internacional. En Alemania no existe la figura del reconocimiento parcial. El examen de la resolución en el sentido de los $\S \S 107$ y ss FamFG cubre tan sólo la disolución del vínculo matrimonial, correspondiendo la apreciación de los efectos accesorios a los tribunales civiles ${ }^{309}$. Ello es problemático porque son frecuentes los supuestos en los que el efecto nuclear del repudio es compatible con el orden público internacional mientras que los efectos accesorios son incompatibles.

Así suele ocurrir con la Haddana ${ }^{310}$, en la que la AP de Guipúzcoa consideró que la atribución de la tutela sobre los hijos al padre por imperativo legal era incompatible con el principio de no discriminación por razón del sexo, aunque admitió el reconocimiento del efecto principal ${ }^{311}$. En un supuesto similar, el AG Hamburg consideró que la Haddana era incompatible con el derecho a ser oído de la madre repudiada, a pesar de que el proceso de disolución de matrimonio respetaba sus garantías procesales ${ }^{312}$.

75. Ante tales supuestos, el art. 49 LCJIMC permite una diferenciación precisa entre efectos compatibles e incompatibles con el orden público internacional. En cambio, al tribunal alemán sólo le queda

${ }^{301} C f$. N. Marchal Escalona, "La eficacia en España de los divorcios extrajudiciales otorgados en el extranjero", Cuadernos de Derecho Transnacional, vol. 13, núm. 1, 2021, pp. 460-492.

${ }^{302}$ Vid. párr. 11.

${ }^{303} C f$. J.A. Corriente Córdoba, "La excepción de orden público en el derecho internacional privado español", Anuario español de derecho internacional, núm. 2, 1975, pp. 125-168.

${ }^{304}$ A. YBARRA Bores, "Los problemas de aplicación del sistema de derecho internacional privado", en A. RodRíGUEz BENOT et al. (ed.), Manual de derecho internacional privado, $6^{\text {a }}$ ed., Tecnos, Madrid, 2019, pp. 149-162.

${ }^{305}$ Cf. J.A. Corriente Córdoba, "La excepción de orden público en el derecho internacional privado español", Anuario español de derecho internacional, núm. 2, 1975, pp. 125-168.

${ }^{306}$ Cf. ibid.

${ }^{307}$ Vid. párr. 59.

${ }^{308}$ Cf. J. Carrascosa González, "Orden público internacional y externalidades negativas", Boletín del Ministerio de Justicia, año 63, núm. 2065, 2008, pp. 5-32.

${ }^{309} \mathrm{Cf}$. Presidente del OLG Koblenz, "Hinweise für das Verfahren auf Anerkennung einer ausländischen Entscheidung in Ehesachen nach § 107 FamFG“, www.olgko.justiz.rlp.de, 2021, p. 6., disponible en: https://olgko.justiz.rlp.de/fileadmin/justiz Gerichte/Ordentliche_Gerichte/Oberlandesgerichte/Koblenz/Dokumente/Anerkennung/HinweisAnerkennungScheidung.pdf

${ }^{310}$ Vid. párr. 38.

${ }^{311} C f$. SAP Guipúzcoa 09/03/2018, FJ 2.

${ }^{312}$ Cf. AG Hamburg 24/01/1985. 
ponderar si la incompatibilidad con el orden público internacional afecta más al efecto principal o a los efectos accesorios, influyendo la calificación del efecto nuclear en la decisión de los tribunales civiles sobre los efectos accesorios. Convendría recoger el concepto del reconocimiento parcial en los $\S \S 107$ y ss. FamFG para agilizar el control de las cuestiones accesorias del repudio, aumentando la seguridad jurídica.

\section{A modo de reflexión final}

76. Las cláusulas españolas y alemanas de orden público internacional funcionan casi idénticas, pues poseen un carácter abstracto y negativo y similares límites: la excepcionalidad, el control de resultado, la exigencia de una incompatibilidad manifiesta y la aplicabilidad parcial de la ley extranjera no incompatible.

Además, los criterios del orden público se uniformizan gracias a que su doctrina excede de la esfera nacional. Los criterios alemanes de la Ergebniskontrolle y del Inlandsbezug son adoptados por los tribunales españoles. No obstante, otros planteamientos se basan en acontecimientos históriconacionales y no se transponen a otros sistemas jurídicos, verbi gratia, la abundante doctrina española de los efectos atenuantes o la simbólica mención especial de los derechos fundamentales en Alemania, que resultó prescindible al no llegar a resultados distintos que el precepto español.

77. El orden público internacional funciona como un "espejo", pues se aprecia una comparación entre lo propio y lo ajeno. En el ámbito de las crisis familiares internacionales, en concreto las particularidades de cada régimen de divorcio, influyen en los criterios de control del orden público internacional. No es menos cierto que, en ocasiones, el uso del orden público internacional frente al repudio se debe a la incomprensión de la figura. Para evitar su rechazo automático y situaciones claudicantes, sería deseable una mejor comprensión de esta institución a nivel europeo.

78. En otro orden, el tenor literal abstracto del art. 10 Reglamento (UE) 1259/2010 aplicable por referencia en España casi automatiza el uso del orden público internacional, mientras que los criterios clásicos de la cláusula alemana minimizan su aplicabilidad.

79. En el ámbito del orden público internacional de ley aplicable, el análisis comparativo entre el sistema español y alemán se convirtió en una "triple comparación" entre la doctrina clásica alemana y española además del novedoso art. 10 (UE) 1259/2010 por referencia. El automatismo de ese último precepto provoca la inversión de la doctrina clásica alrededor del orden público internacional. En el marco de un proceso de materialización orden público internacional, el legislador europeo pretendía implementar el principio de igualdad como principio informador con vigencia directa y absoluta ${ }^{313}$. Aunque su intención es encomiable, el carácter abstracto del art. 10 tiene un efecto nocivo porque choca con los criterios clásicos del orden público internacional.

El ejemplo de España demuestra que el art. 10 pone en cuestión la aplicabilidad de aquellos criterios que restringen el uso del orden público internacional. En suma, sólo seguirán operando frente al repudio si el legislador español introdujese una remisión al art. $12.3 \mathrm{CC}$, tal como sucedió en Alemania dónde se mantiene el control clásico del orden público internacional con un foco en el Inlandsbezug y la Ergebniskontrolle. En relación con el repudio, el criterio de control del resultado resulta imprescindible para ponderar los intereses individuales de los cónyuges. No obstante, la interpretación estricta del consentimiento de la mujer en Alemania provoca el mismo resultado que el art. 10 Reglamento (UE) 1259/2010. El carácter formalmente discriminatorio de la ley extranjera impide su aplicación al divorcio ante un tribunal alemán o español.

80. El contraste entre la solución de la doctrina clásica española y alemana frente al novedoso art. 10 se agravia en el ámbito del orden público de reconocimiento. En ambos países, el repudio ca-

${ }^{313}$ Vid. cons. 30 RRIII. 
lificado como acto judicial se somete al control restrictivo del orden público internacional en sede de reconocimiento que opera raras veces. Igualmente, el reconocimiento sustantivo del repudio con intervención declarativa se homologa a un supuesto de orden público de ley aplicable, provocando en España una discrepancia intolerable entre el trato de la mujer repudiada con y sin intervención constitutiva.

81. Debido a la influencia dominante de los preceptos fundamentales con vigencia universal, el criterio de conexión espacial es cada vez menos relevante. Convendría que los tribunales alemanes los invocasen con más frecuencia, tal como ya ocurre en España ${ }^{314}$. Ello conlleva un gran potencial para el uso futuro del orden público internacional, en tanto que un principio tenga la consideración de esencial en la mayoría de los estados, activarlo sería sencillo contando con el respaldo de la comunidad internacional. No obstante, ello no debe acabar con la priorización de ciertos valores, tales como el principio de igualdad que tiene un alcance quasi-universal ${ }^{315}$.

82. De todos modos, el monopolio estatal de disolución del divorcio existente en Alemania y España no es representativo a nivel global. La disolución extrajudicial del matrimonio es un fenómeno cada vez más frecuente que busca agilizar los trámites y reducir la carga de trabajo a los tribunales ${ }^{316}$. La historia del orden público español demuestra que la aceptación de ciertos resultados del repudio a través de los efectos atenuantes podría suponer un índice de que ciertos elementos del orden público internacional hayan quedado obsoletos. No parece improbable que, en un futuro cercano algún tribunal alemán o español active el orden público internacional contra leyes extranjeras que no permiten el divorcio sin intervención judicial.

El divorcio se caracteriza por un dilema entre la protección de la parte más débil y el libre desarrollo de la personalidad de los cónyuges. Los criterios propios del orden público internacional sirven para ponderar los derechos de igualdad y de la libertad de los litigantes extranjeros. De la comparación entre los artículos 10 Reglamento (UE) 1259/2010 y las cláusulas nacionales de orden público internacional resulta que las últimas son más útiles para conseguir la "justicia material en el caso concreto" 317 .

Ciertamente, un futuro orden público internacional europeo tiene potencial para reforzar la tutela de los principios esenciales compartidos, pero sin obviar la "vía normativa" del art. 10 Reglamento (UE) 1259/2010, la doctrina clásica del orden público internacional junto con una "vía interpretativa" para conseguir resultados justos ajustados al caso concreto ${ }^{318}$. Para ello, es imprescindible que el orden público internacional mantenga su carácter "móvil, flexible y fluctuant 319.

83. Del análisis del orden público internacional español y alemán se deduce que la imposición rigurosa de principios abstractos pueda vulnerar los intereses individuales del litigante. Por ello, un futuro orden público internacional europeo no debe ser un orden público de única dirección, sino un orden público de protección que garantice los derechos fundamentales de los individuos ${ }^{320}$.

314 Vid. e.g. SAP La Rioja 7/04/2014, FJ 2.

${ }^{315}$ C. STAATH, „La excepción de orden público internacional como fundamento de denegación del reconocimiento del repudio islámico", Anuario Español de Derecho Internacional Privado, núm. 10, 2010, pp. 717-729.

$316 C f$. N. Marchal Escalona, "La eficacia en España de los divorcios extrajudiciales otorgados en el extranjero", Cuadernos de Derecho Transnacional, vol. 13, núm. 1, 2021, pp. 460-492.

${ }^{317} C f$. H. Aguilar Grieder, "Multiculturalidad, reconocimiento en España de repudios islámicos pronunciados en el extranjero y actuales tendencias del orden público en el D.I.Pr.", Cuestiones actuales de derecho comparado: actas de las reuniones académicas celebradas el 13 de julio de 2001 y el 10 de octubre de 2002 en la Facultad de Derecho de A Coruña, 2003, pp. 235-264.

${ }^{318}$ Ibid.

${ }^{319}$ ATS 24/10/1997.

${ }^{320}$ A.L. Calvo Caravaca \& J. Carrascosa González, "Crisis matrimoniales”, en A.L. Calvo Caravaca \& J. Carrascosa GonzÁlez (eds.), Derecho Internacional Privado: Vol. II, $18^{\text {a }}$ ed., Comares, Granada, 2018, pp. 227-314. 